\title{
Laurids Skau og Goldschmidt \\ En skildring på grundlag af breve og artikler
}

\author{
Af $H . V$. Gregersen.
}

„Laurids Skau korresponderede med det halve Danmark... lige fra sit 20. år... og i meget forskellige retninger, med den danske sag som hovedsag «, hedder det et sted i et brev fra broderen Peder Skau, ${ }^{1}$ og til dette »halve Danmark har han givetvis regnet 1840'rnes liberale opposition, mænd som H. N. Clausen, Orla Lehmann, Carl Ploug, A. F. Tscherning og "Corsaren "s redaktør Meir Aron Goldschmidt. Laurids Skaus brevveksling med de tre førstnævnte "politiske venner" $i$ hovedstaden er nu udsendt $\mathbf{i}$ bogform, og hans forbindelser med A. F. Tscherning er stort set tilgængelig i udgaven "Af Anthon Frederik Tschernings efterladte Papirer". I-III, 1876-78, og ved offentliggørelsen af $\gg$ Et par breve fra A. F. Tscherning til Laurids Skau * i Sønderjyske Årbøger 1963. Også hans brevveksling med Goldschmidt foreligger nu, nemlig på nær et par nyfundne breve fra januar 1846 - i Morten Borups udgave "Breve fra og til Meir Goldschmidt ", I-III, 1963.

Laurids Skaus kontakt med Goldschmidt blev ikke langvarig. Den begyndte engang i 1844, noget for det store Skamlingsbankemøde, og sluttede med »Corsaren «s standsning i 1846 og Goldschmidts påfølgende udenlandsrejse. I martsdagene 1848 stod de klart i hver sin lejr, og de synes ikke senere at have nærmet sig til hinanden. Goldschmidt omtaler overhovedet ikke Laurids Skau i sine » Livs Erindringer og Resultater «, I-II, 1877, ej heller Peter Chr. Koch, med hvem han vekslede nogle få breve. ${ }^{2}$ Kun nævner han den skelsættende betydning, som Peter Hiort Lorenzens optræden i Slesvigs stændersal i 1842 fik for ham og hans samtidige. ${ }^{3}$ Forbindelsen mellem Laurids Skau og Goldschmidt blev således kun en kort episode $i$ de to mænds tilværelse, og alligevel 


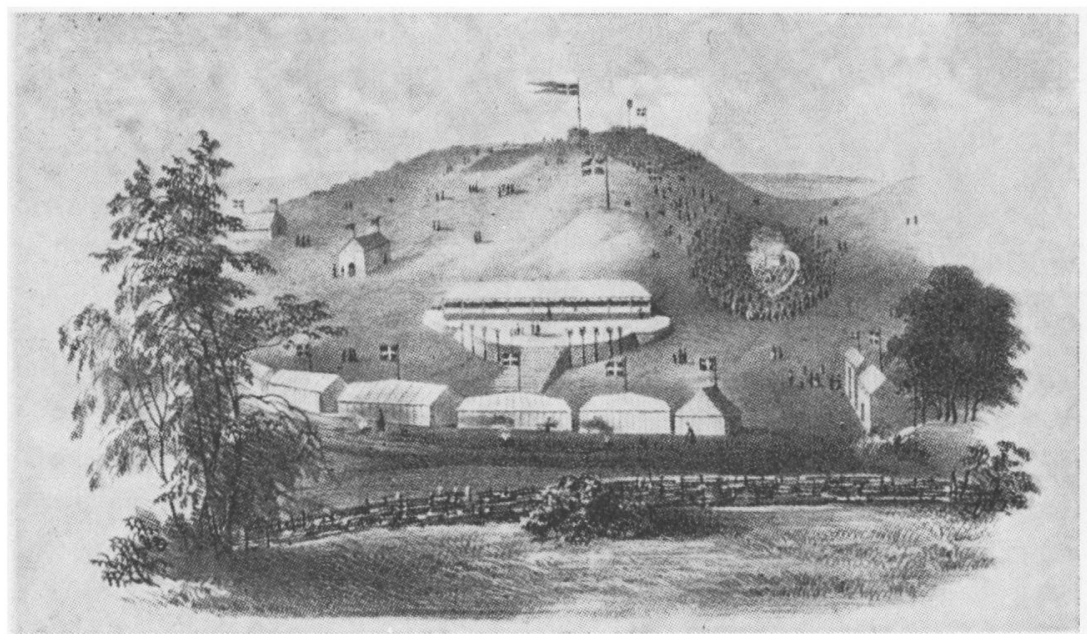

„Festen på Højskamling d. 4. Juli 1844. kaldes denne litograf, der findes på Frederiksborg Museet.

var der tilløb til en tilnærmelse mellem deres standpunkter, hvilket ikke mindst det ene af de nyfundne breve fra 1846 tyder på.

2: Digteren Goldschmidts navn vil for stedse være knyttet til Sønderjyllands historie på grund af hans deltagelse i Skamlingsbanke-mødet $4 / 7$ 1844. I sine erindringer har han betroet sine læsere, hvorledes festkomitéens anvisning af logi til ham hos en jøde $\mathrm{i}$ Kolding ramte hans sensible sind og fik vidtgående følger for hans forfatterskab såvel som for hans tale ved Skamlingsbanke-festen. Han skriver således følgende om festen, som han fejlagtigt henlægger til maj måned: ${ }^{4}$

»Denne fest var en folkelig besiddelsestagen af Sønderjylland, en højtidelig planten af flaget på dets grund, og som forholdene var, kunne det ikke ske i det sydlige Slesvig eller blot i midten, men tæt ved Jyllands grænse. Landingsstedet for os københavnere var derfor Kolding.

Overfarten var i sandhed skøn, fordi der var majdag i os som i selve naturen, det spirede $i$ os med håb og glæde, den nye fuglesang lød, vi var i den danske nations forårsmorgen og bar den med os. 
Jeg havde levet ombord i fuldstændig og ublandet dansk luft, følt mig indoptaget $\mathbf{i}$, del af den danske nationalitet, haft en lykkelig dag. Ud på eftermiddagen kom, hvad der vel også hændes andre, efter den lange selskabelighed en vis sindets træthed, en nedstemthed eller sørgmodighed, der forøgedes, da vi nærmede os Kolding, og det foreløbige mål fik form, blev mindre eller anderledes, end det var tænkt. Formodentlig blev jeg derved mere modtagelig for det forstyrrende eller skærende, da vi lagde til broen, og en mand trådte frem med velkomsthilsen og derpå med høj røst anviste hver af os bopæl, mig hos en jøde. Jeg havde naturligvis intet imod min ubekendte blodslægtning, men jeg følte det på den måde, at vi nu ikke længer var danske, der skulle til danske, men kristne til kristne, jøder til jøder, hver i sin bås. Det var jo ikke sådan ment, men med min sensibilitet opfattede jeg det sådan, og da Ove Thomsen ${ }^{5}$ tidligere på dagen havde foreslået mig, at vi slet ikke skulle blive i Kolding, men straks tage ud til Vonsild, ved foden af Skamlingsbanke, og nu fornyede opfordringen, tog jeg derimod, og vi forsvandt.

I visse måder var dette en lykkelig beslutning, thi der blev os en mageløs herlig aften til del $i$ Vonsild kro. Vi sad på en trappe ud til haven og så et stort blus i det fjerne; det var et glædesblus tændt på Skamlingsbanke i anledning af vort komme. Der var i natten og dens blus noget romantisk, halvt krigersk, en luftning fra Valdemar Sejrs tid; vi var som fortropper af den danske befrielseshær. Mænd og kvinder kom og hilste på os og talte med os, som fremmede mennesker ellers ikke taler til hinanden. Vi lyttede til hverandres stemmer og fandt dem danske. Ordene var danske i slesvigsk mål. Medens det blev tyst om os, vedblev det store bål at brænde hist oppe, noget syntes at blive forkyndt mellem himmel og jord.

Men da vi så ud på natten skulle have et par timers søvn, kom den tanke, at nu var der i Kolding en familie, som jeg havde været uhøflig imod og måske følte sig krænket af mig, blodslægtningen, jøden, som om jeg ikke havde villet vedkende mig slægtskabet. Hvor var skylden, hos mig eller hos de ildesindede indkvarteringschefer? Jeg fik ingen søvn og var om morgenen som i feber. På Skamlingsbanke blev det ikke bedre. Deroppe på toppen, nærved talerstolen, traf jeg en bekendt, en litterat og døbt 
jøde, der spurgte mig, hvor jeg var blevet af den foregående aften. Jeg fortalte ham det og tilføjede, at jeg nu kunne have lyst til at stige op på talerstolen og råbe ud til alverden, at jeg var jøde. Han sagde: Jeg vædder, at De ikke tør sige højt, at De er jøde. - Det kunne der ikke væddes om, men få sekunder efter stod jeg på talerstolen og sagde det til de mange tusinde mennesker: Jeg er en jøde, hvad vil jeg imellem jer?

Det var mit livs store spørgsmål, som jeg på begrænset, omhyllet, dunkel måde bar i mig og kastede ud.

Det blev mødt med et umådeligt råb: Jo, jo! velkommen! og de nærmeste rakte hænderne op imod mig. Dette burde have inspireret mig til, eller det kunne hos en anden have frembragt sand veltalenhed om nationalitet og frihed, men der var feber og disharmoni i mit sind - noget vredt og ondt ved siden af selvbebrejdelsen -, og jeg fortsatte med at forklare, hvorfor jeg som jøde stod der med dette: Fordi jeg bragte dem ordet $» ø$ je for øje og tand for tand ", fordi det ikke gik an, som foreskrevet fra anden side, at vende kinden til, når den blev slået, men slå igen på slesvigholstenerne, hårdt mod hårdt, ondt mod ondt, gøre gilde for dem, som de ville for os!

... På langt hold gav talen på Skamlingsbanke et stød til fortællingen "En Jøde.

Peder Skau har fortalt Goldschmidts biograf Hans Kyrre, ${ }^{\circ}$ at der var et spottende smil om Goldschmidts mund og ironi $\mathrm{i}$ tonen, da han indledede med sit spørgsmål. Men Goldschmidts slutningsreplikker gik heller ikke upåagtede hen, da han omskrev det gammeltestamentlige gengældelsesord: „Når slesvigholstenerne vil give jer på hovedet, så skal I give dem lige så meget på hovedet... Derfor et hurra for et lystigt gilde med slesvigholstenerne på gammel-jødisk manér! «"

Man har i al almindelighed glemt, at Goldschmidts tale på Skamlingsbanke fik et efterspil, som måske er forklaringen på, at pastor Marckmann over for $\mathrm{Koch}^{8}$ gav udtryk for, at det nok ikke var tilrådeligt at gøre brug af Goldschmidt ved næste års sammenkomst på Skamlingsbanke. Slesvigholstenske kredse udnyttede nemlig talen ved at slå mønt af den ukristelige moral, som her var anslået. "Jøden Goldschmidts frækhed at drage en parallel mellem kristendom og jødedom går desværre fra mund til mund og frem- 
kalder endog hos den roligste og redeligste en sådan forbitrelse, at det kunne medføre de sørgeligste følger, hvis en sådan forhånelse af religionen og fædrelandet skulle blive gentaget «, hedder det ret omgående $i$ Altonaer Mercur «s referat ${ }^{2}$ fra festen.

For landsdelens kirkelige kredse var Goldschmidts ordvalg noget hidtil uhørt og på ingen måde egnet til at gøre den danske folkesag velanskreven hos kristeligt vakte mennesker. Det er måske ikke for meget sagt, at der går en direkte linje fra Goldschmidts tale på Skamlingsbanke i 1844 til den slesvigske præstestands altovervejende anerkendelse af den provisoriske regering $i$ 1848. At Claus Harms's mange disciple ikke har kunnet godtage indholdet af denne tale, vidner efterstående indignerede skildring i » Flensburger Religionsblatt $\star^{10} \mathrm{om}$ :

"Mange tusinde, som kalder sig kristne, har tiet til en tale, som blev holdt på Skamlingsbanke. Det var den tale, hvori en jøde for nogle uger siden antastede og hånede den hellige tale, som vi kalder Kristi bjergprædiken. I sandhed! siden Kristus vandrede her på jorden, er noget sådant ikke sket $\mathrm{i}$ kristenheden, og forfærdelsens mål er også fuldt i deres hjerte, som endnu elsker deres Frelser. 1 året 1844 turde en jøde tale således til mere end 5000 kristne. En frygtelig bespottelse hørte tusinde af kristne på hin høj, og de tav, skønt det dog kun havde været ret og pligt at stoppe munden på en sådan farisær med hans talmudiske retfærdighed ". "Sønderborger Ugeblad " var ikke sen til at henlede opmærksomheden på, at heller ikke de tilstedeværende præster havde følt sig foranledigede til at gøre indsigelse. Hermed var der vel i særlig grad tænkt på Hans Wilhelm Hertel, Laurids Skaus gode ven, som var præst i Moltrup-Bjerning, men selveste Grundtvig havde også været blandt tilhørerne.

Laurids Skaus kristelige ballast tyngede ikke så stærkt, at han på nogen måde kunne føle sig stødt af Goldschmidts opfordring til at gengælde øje for øje, tand for tand; tværtimod, og han glemte da heller ikke Goldschmidts råd, da han aflagde beretning til denne om Peter Hiort Lorenzens slagsmål i *Borgerforeningen « i Haderslev. ${ }^{11}$

3: Skamlingsbanke-stævnet indledede det personlige bekendtskab mellem Laurids Skau og Goldschmidt. Laurids Skau havde 
været festens hovedtaler, og selv om Christian Flor havde forfattet talen, forstod Skau på sin egen måde at iklæde den oratorisk kraft. Alle, der har overværet mødet, har været enige om, at den blev holdt med stor dygtighed, og det var derfor selvfølgeligt, at den blev modtaget med vældig begejstring, ikke mindst af de mange tilstedeværende københavnere, thi ingen af de ledende sønderjyder kunne hverken i tale eller form måle sig med den unge, stoute bonde fra Sommersted. Selv Skaus skarpeste kritiker, Peder Lauridsen, har senere måttet dømme: »Den unge Laurids Skau vil aldrig $\mathbf{d ø}{ }^{12}$

Goldschmidt udgjorde i så henseende ingen undtagelse. I et brev til sin redaktørkollega Peter Christian Koch skrev han kort efter festen: ${ }^{13}$ " ... Hjertelig tak for sidst, kære danske mand. De gør Dem ikke nogen forestilling om det indtryk, jeg modtog; jeg har aldrig været så inderlig glad, så lykkelig som den dag, især i det øjeblik, da Laurids Skau talte. Thi hans tale var festens koncentration, dens brændpunkt; alle de andre taler kunne gerne have været borte. Det er en mageløs karl, den Laurids Skau; blot den megen virak ikke bedøver ham. Man har givet ham en for stor portion på eengang; man betænker ikke, at han ikke er vant dertil" .

Allerede på den tid var der altså nogen reservation i Goldschmidts bedømmelse af Skau. Om denne skyldes eget klarsyn, eller om han under Skamlingsbanke-mødet hos Koch har modtaget et vist korrektiv til den gængse Skau-begejstring, lader sig ikke oplyse, men vi ved, at Koch ikke betragtede den yngre og i ydre form og optræden langt sikrere Skau med udelt begejstring. "Lad det korte bekendtskab, vi har gjort, blive næret", hedder det videre i Goldschmidts brev til Koch, og den tanke melder sig da, om Goldschmidt ville have udtalt sig så åbent om Skau til Koch, dersom han ikke havde haft fornemmelsen af, at en reserveret indstilling over for Skau ville blive optaget med velvilje af Koch.

Hans brev til Koch nogle dage senere ${ }^{13}$ synes at bestyrke denne formodning, og selv virker Goldschmidt endnu mere sikker i sin opfattelse af Skau:

"Laurids Skau findes slet ikke omtalt [i »Corsaren «] i anledning af Skamlingsbanke-festen. Det er gjort med vilje. Midt under den virak, der omdufter ham, har han godt af en lille tilsidesættelse, en "memento mori«. Vore høvdinge begår en forfærdelig fejl ved 


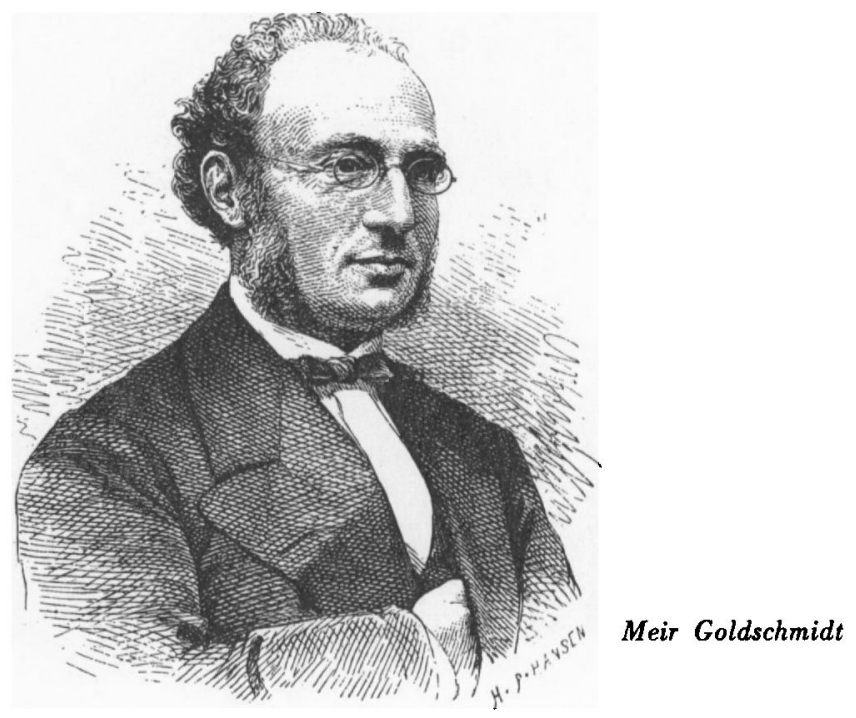

at gøre tor meget af Laurids Skau. De trækker ham op til sig, men derved risikerer de at trække ham fra bønderne, og hvad er Laurids Skau uden sin bonde-indflydelse? Gid man aldrig må komme til at fortryde denne adfærd. Jeg elsker og beundrer Laurids Skau, jeg anser ham for et mærkværdigt, genialt menneske; men netop derfor skal han behandles omhyggeligt «.

Goldschmidts brev skyldtes hans løfte om at overlade Koch 100 eksemplarer af *Corsaren «, 1844 19/7 til uddeling blandt interesserede. Heri fandtes følgende om Skamlingsbanke-mødet:

- Danmarks stærkeste fæstning er anlagt på Skamlingsbanke. Oven på toppen af Højskamling er opkastet en redoute, der rigtignok kun er besat med seks kanoner, men, hvilket øjeblik det skal være, har man 12.000 mennesker til at betjene dem.

Disse 12.000 mennesker samles på følgende måde: bønderne fra Sommersted, Vonsild, Hjerndrup, Tyrstrup og Gram rykker først op og planter Dannebroge. Ved foden af bakken sejler dampskibet * Maagen c ind, besat med fynboer. Jyderne kommer frem fra Dalby hulvej og efter dem københavnerne under sangen: *Ur vägen, Moscoviter « ${ }^{14}$

Armeen mangler kavalleri, men, når den kommer ind i Schleswigholstein, vil den finde heste nok. Men forresten er armeen godt 
forsynet; den har endog sin feltpræst, den gamle Grundtvig: den hvidhårede digter og præst, hvis tro tilhører kristendommen, hvis hjerte den nordiske hedenold; som før kampen taler fredens og velsignelsens ord og under kampen slår så godt som nogen.

Den danske hær er samlet på Skamlingsbanke. Du vil holde revy over dine soldater ved Horsens, kong.Christian. Her er en hær, kong Christian, hold revy over den. Vagtblussene brænder i natten og lyser milevidt; de lyser efter dig, kong Christian *.

Kun med vendingen sbønderne fra Sommersted * var Laurids Skau blevet antydet som deltager i Skamlingsbanke-festen, og han har naturligvis intet kunnet ane om Goldschmidts kritiske holdning. Tværtimod opretholdt Skau forbindelsen med Goldschmidt og besøgte ham endog under sit ophold $i$ København i slutningen af 1844. "Glædeligt nytår! og god sejlads for >Corsaren \&! Vil De på mine vegne onske Deres karakteristiske far, interessante mor og skønne søster et velsignet nytår og mange glade dage, samt formelde dem min tak for den velvillige opmærksomhed, som de viste mig sidste gang, jeg var i København", hedder det i slutningen af Skaus brev, ${ }^{15}$ der $i$ ovrigt indeholder Skaus skildring af Peter Hiort Lorenzens slagsmål i \#orgerforeningen* i Haderslev.

4: Til Skaus dyder som politisk leder hører vel også, at han besad et klart blik for den folkepsykologiske betydning af den politiske satire. Hertil kunne han bruge Goldschmidts "Corsaren som i sin korte levetid fra 1840 til 1846 havde vundet ry ud over det ganske land som satirisk samfundsrevser. Ganske vist glippede hans første forsøg på at levere stof eller give tips om stof, der kunne egne sig for vittighedsbladet. Hvad det drejede sig om, ved vi ikke. Vi har kun Goldschmidts svar, et udateret brev, ${ }^{16}$ hvori det hedder: "Da vi folger det princip at omtale slesvigholstenerne så lidt som muligt, for at vore ord, når vi omtaler dem, kan have desto mere virkning, så har vi ikke kunnet benytte Deres ærede meddelelse, der omhandler en sag, der engang har været genstand for påtale $i \mathrm{i}$ "Corsaren « *. Brevet er åbenbart affattet, inden Goldschmidt lærte Skau personligt at kende, thi han slutter det: „Vel sandt, vi kender Dem ikke og ved altså ikke, om vi kan stole på Dem - imidlertid: den hånd, hvormed Deres brev er skrevet, er en gentlemans *. 
Meget tyder på, at Skau har været mere heldig som bidragyder til "Corsaren « $i$ anledning af Christian VIIIs besøg i Haderslev og omegn i sommeren 1844. I sit brev til Carl Ploug $18445 / 8^{17}$ siger Skau om denne rejse: "Ypperligt stof til "Corsaren"!" og i "Corsaren « 1844 16/8 læser man næsten i overensstemmelse med Skaus ovennævnte brev til Ploug:

"Jeg ankom, netop som kongen stod mellem de 40 sognefogder, og den lange Erich $^{18}$ takkede kongen for patentet af 29. marts. Jeg var nærved at briste ud i en skoggerlatter af ærgrelse, da pludselig de andre sognefogder gjorde en næsten umærkelig bevægelse fremad, og en lille én blandt dem sagde: Ja, men det mener vi ikke. Kongen drejede sig uvilkårligt, og i amtmand Johannsen gav det et sæt, som om han fik sting. Nu påfulgte hin allerede andetsteds fra bekendte scene, da kongen sagde: Jeg er en dansk konge, og den, der siger, jeg er tysk, farer med usandhed...

Jeg var ikke i Hammelev kirke, men jeg fik en beretning derom fra første hånd. Det var på et hængende hår, at bønderne aldeles havde erobret kongen for sig mod Johannsen og consorter. Bønderne trængte under anførsel af Hans Skau (dette navn er ominøst i Slesvig) frem med [Algreen-]Ussingsk sejghed, klager på klager regnede ned som kartæsker, Kjær [herredsfoged Kier] tænkte allerede på retirade, amtmand Johannsen vendte alt ryggen, da kom et hjælpekorps, som sendt fra himlen: pastor Andresen angreb bønderne i ryggen som ditmarskerne fordum Valdemar Sejr ved Bornhøved, sprængte deres slagorden, trængte sig hen til kongen og skilte ham ved sin velsignelse fra bønderne.

Første gang, vi med fuld sikkerhed er i stand til at fastslå Skaus paternitet med hensyn til stof fra Haderslev-egnen i "Corsaren", er $i$ anledning af dette blads omtale af »Slaget i Haderslev", der pudsigt nok er blevet optaget to gange (1845 17/1 og 24/1) med samme ordlyd, men med forskellige tegninger. Skaus meddelelse om denne batalje er dateret $18458 / 1^{19}$ og har følgende ordlyd:

"I dette øjeblik var det måske dog ikke overflødigt at skrive Dem nogle linjer for at give Dem en autentisk beretning om den første batalje, der er forefaldet mellem danskerne og slesvigholstenerne, der foregik i overensstemmelse med Deres råd, som De gav os på Skamlingsbanke, det nemlig: „Når slesvigholstenerne giver os på hovedet, så skal vi give dem på hovedet igen o.s. v.s 


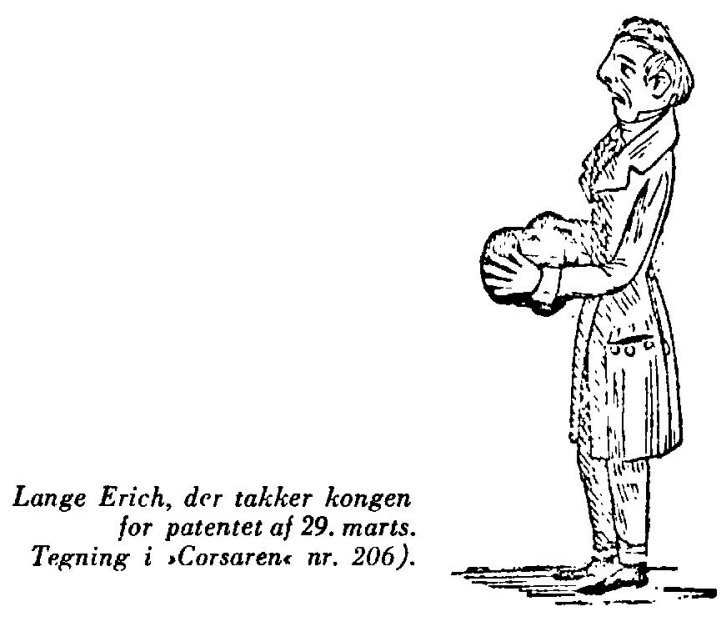

Vi var blevet enige om at holde os sammen for at passe på de rebelske faner, hvis man vovede at udhænge dem ved kronprinsens gennemrejse den 2 . januar...

Da nu kronprinsen var ledsaget ud af byen, traf en del danske borgere og bønder sammen hos [Peter Hiort] Lorenzens svoger, gæstgiver Otto $\mathrm{H}$. Schröeter, hvorfra vi trak los til »Borgerforeningen" og gik ind i den offentlige skænkestue, hvor blot advokat Stibolt og to andre borgere befandt sig. Jeg forlangte en bolle afbrændt vin, som værten bragte os, og , vi drak nu, i forening med de 3 slesvigholstenere, på et glædeligt nytår. Derpå sang man: »Norden, gamle Norden" m. m., fremdeles "Der er et land, dets sted er højt mod norden " o. s. v., hvorpå man drak kronprinsens skål. Jeg sad ikke tilbords hos de andre, men gik omkring og passiarede med de forskellige slesvigholstenere, som efterhånden var kommet ind (for at passe på, at der ikke lagdes råd op imod os.) Nu istemtes: „Vift stolt pâ Codans bølge«, og da denne var til ende, rejste P. H. Lorenzen sig og udbragte en skål for gamle Dannebrog, at den stedse måtte vaje stolt, til trods for alle oprorske faner og emblemer, o. s. v. Der var imidlertid trængt en flok slesvigholstensksindede borgere ind i stuen, hvoriblandt borgerofficeren Burmester, Raben - som tillige er postholder og var klædt $i$ sin røde postholderdragt - , T. Schley. Disse havde uni- 
form på, men spændte sablerne af og satte dem hen $i$ en krog.

Da nu Lorenzen talte, begyndte disse herrer, der stod $i$ en klynge henne ved doren, at bræge forfærdeligt, og nogle opslog en hånlatter; den, der brægede, efterlignede så naturligt fårenes lyd, at man skulle have troet, at det virkelig var făr, hvis ikke man havde vidst, at det var Haderslev-borgere, som var kommet ind $i$ stuen. Men herover blev Lorenzen formodentlig vred, thi han vendte sig nu fra bordet imod de brægende herrer og spurgte, om der var nogen iblandt dem, der hyldede de rebelske faner, så skulle de komme frem o. s. v.

$\mathrm{Nu}$ for de ind på ham og de andre danske borgere, som havde stillet sig ved hans side, og begyndte en meget respektabel nævefægtning. Lorenzen tog en stol og holdt for sig som skjold, men han slog ikke; derimod kom gæstgiver og postholder samt borgerofficer Raben, i sin røde uniform, og tømrede løs med begge næver, på hvem han kunne ramme. - Schley, der også som ovenmeldt er officer, udmærkede sig også $\mathrm{i}$ at slå.

Jeg tog ikke del i bataljen, men vedblev at passiare med nogle borgere, der ligesom jeg så på kampen; sommetider stod jeg stille og med korslagte arme stod og betragtede dette aldrig før sete skuespil.

Da netop larmen var stærkest, kom den lille tykke borger og værtshusholder Hans Bertelsen farende ind, og et øjeblik efter fik han bersærkergang; thi han tog en lysestage og slog dermed til alle sider på alt, hvad han kunne ramme, skånede hverken ven eller fjende, borde eller stole; og i denne fart formoder jeg, at han uvægerlig har truffet den gamle sadelmager Bungartz $i$ hovedet, da jeg netop i dette ojeblik bemærkede, at han havde et sår i panden, der så ud til at være forårsaget ved et sligt våben, som det Bertelsen med så stor iver førte. Jeg bestyrkedes i denne tro derved, at ingen af de andre havde synlige våben at slå med.

En nordmand, som hjalp de danske, havde 4 slesvigholstenere fået ned på gulvet og slæbt $i$ håret $u d$ af stuen, men $i$ døren kom en kæmpestærk bonde til og viftede disse 4 helte bort og således frelste nordmanden, der øjeblikkelig tog anstændig hævn. Nu ophørte tildels kampen, efter at omtrent 20 vildtyskere var hårdt sårede, hvorimod kun een dansker havde et synligt sår, og de fjernede sig nu alle, hvorimod Hans Skau fra Styding og jeg blev 

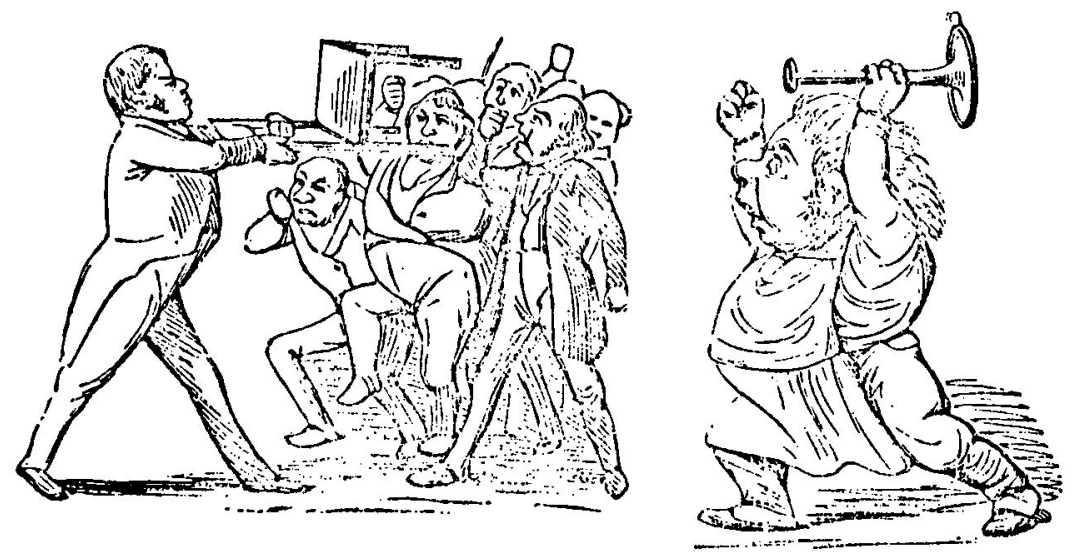

Peter Hiort Lorenzen forsvarer sig under slaget $i$ „Borgerforeningen“ $i$ Haderslev. Borger og voertshusholder Hans Bertelsen angriber med en lysestage.

(Efter , Corsarens nr. 227).

ene tilbage for at sige ordentlig godnat, og tillige vise borgerne, at vi ikke var bange, endskønt vi kun var to personer ".

I »Corsaren " $184517 / 1$, samt 24/1, har Goldschmidt i vid udstrækning benyttet Skaus ordlyd og vendinger, hvilket vil fremgå af efterstående udtog: "Derfra begav de [d. e. slesvigholstenerne] sig op i »Borgerforeningen "s lokale, hvor Peter Hiort Lorenzen med flere danske borgere og bønder ligeledes indfandt sig og forlangte en bolle afbrændt rødvin, i den hensigt at drikke den. Flere slesvigholstenere kom til, og da Peter Hiort Lorenzen udbragte en skål for "gamle Dannebrog, der stedse skulle vaje stolt til trods for alle oprørske faner «, begyndte slesvigholstenerne at bræge så forskrækkeligt og med en sådan virtuositet, at man skulle have troet, det var virkelige får.

Peter Hiort Lorenzen blev nok vred over dette uskyldige tidsfordriv, thi han vendte sig om og sagde, at hvis nogen holdt med de oprørske faner, kunne han træde frem. De gjorde mere, end han bad om - de sprang frem, de for frem, de styrtede frem og los på ham og de danske. Peter Hiort Lorenzen greb en stol, hvormed han holdt angriberne fra livet, men på de andre punkter af stuen opstod et hårdnakket håndgemæng.

Da slaget rasede på det stærkeste, kom borger og værtshusholder Hans Bertelsen ind, og straks blev han grebet af bersærker- 
gang. Han greb en lysestage og slog dermed den første den bedste. Skæbnen ville, at denne skulle være hans egen ven, regimentssadelmager Bungartz, i det mindste har man senere fundet hr. Bungartz med et sår, hvori lysestagen passer.

Denne lille episode, hvori regimentssadelmager Bungartz blev slået til ridder af lysestagen, havde ingen videre indflydelse på slagets gang. Det rasede fortsat, og mærkeligt var det da at høre, hvorledes slesvigholstenerne, der $\mathrm{i}$ begyndelsen havde skældt ud på tysk, alt som de blev varme, talte dansk, og hvorledes Peter Hiort Lorenzens parti besvarede begge sprog med gammeldanske prygl.

Striden antog et øjeblik en ren skandinavisk karakter. Fire slesvigholstenere havde fảet fat $i$ en nordmand, der var med de danske, og hvem de ret syntes at ville vise, hvor liden fordel nordmændene vil have af en union. De kastede ham omkuld og slæbte ham ved hårene for at kaste ham ud. Men her viste sig ret krigslykkens ustadighed, thi $i$ døren mødte dem en dansk bonde, og efter et øjebliks kamp var det ikke nordmanden, men slesvigholstenerne, der kom udenfor.

Efter at tyve vildtyskere var blevet mere eller mindre sårede, sagtnedes kampen, og endelig kunne de danske kampere på valpladsen.... .

Goldschmidts egen tilføjelse $\mathrm{i}$ omtalen af denne episode, hvormed Peter Hiort Lorenzen i virkeligheden beseglede sin egen politiske dødsdom, er det lille hib til skandinavisterne, som Goldschmidt ikke havde meget tilovers for.

5: I de følgende måneder var der tavshed mellem Skau og Goldschmidt, men denne tavshed havde vel forst og fremmest sin årsag i det politiske dødvande, der var indtrådt i forbindelse med Peter Hiort Lorenzens pludselige død i marts 1845. For Skaus fremtid var denne begivenhed noget afgørende, for trods sin ungdom blev han nu anset for at være lederen af den danske opposition i Nordslesvig. "Syvstjernen" i København skaffede ham midler til køb af en større gård i Hovst i Vilstrup sogn, hvilket var en forudsætning for at blive valgbar til stænderforsamlingen. "Ved Lorenzens død er der lidt et tab, som især er føleligt med hensyn 
til den stænderske virksomhed. Men de danske slesvigere har endnu en talsmand $i$ deres midte, som derhos er $i$ den egentligste betydning den danske nationalitets naturlige repræsentant. Laurids Skau, udgået af en kernefuld bondestand, er af byrd og dannelse ren dansk, og forsynet har $i$ ham givet en forening af egenskaber, af åndens og talens gaver, der gør ham til en folkerepræsentant $\mathrm{i}$ ordets højeste betydning og anviser ham en mærkværdig stilling i den nærværende tids krise". Således lød de ord, hvormed »de syv"s indsamlingskomité præsenterede den nye leder af den danske bevægelse. ${ }^{20}$

Goldschmidt tav foreløbig til al denne virak, men med "Corsaren "s omtale af Skamlingsbanke-festen 1845 18/7 fik hans tanker mæle. ${ }^{21}$ Skau havde atter været hovedtaleren, men hans tale var denne gang noget mat. Den var nærmest formet som en oversigt over årets vigtigste begivenheder, og herunder hyldede Skau den unge kvinde, der under navnet "Frøken Valgerda ${ }^{22}$ havde henvendt sig $\mathrm{i}$ et åbent brev til den tyske professor Ernst Moritz Arndt. Goldschmidt havde allerede tidligere $i$ "Corsaren " ${ }^{23} \mathrm{i}$ en ironisk henvendelse til Kochs "Dannevirke" hævdet, at pseudonymet "Valgerda" dækkede over en mandsperson. Kvinders offentlige optræden var jo dengang noget højst usædvanligt. $\mathrm{Nu}$ tog Goldschmidt tråden op, da han i en endog meget kortfattet omtale i "Corsaren" af Skamlingsbanke-festen skrev »Froken Valgerda! - Man kan mærke på Laurids Skau, at han kommer meget til København, siden han nu sågar kalder et mandfolk frøken".

Skaus svar forelå prompte: ${ }^{24}$ "Af "Corsaren "ser jeg, at De antager Valgerda for et mandfolk (hvis jeg nemlig forstår Dem rigtigt), og jeg må derfor til berigtigelse heraf fortælle Dem, at jeg ikke alene ved et tilfælde lærte at kende Valgerda, ${ }^{25}$ da jeg rejste hjem fra København, men så endog koncepten til den afhandling, som fra hende sendtes til "Fædrelandet ", og efter den times samtale, jeg havde med hende, at dømme, er det slet ikke utroligt, at hun selv ikke alene har skrevet, men også forfattet hele brevet til Arndt. Dette var grunden til, at jeg brugte hende for at give mændene på hovedet, uden at jeg personlig udsatte mig for vore uslinges raseri... At jeg i København har lært at kalde et mandfolk frøken, vidste jeg ikke, før De nu fortæller det«.

Videre i brevet beklager Skau, at Goldschmidt ikke denne gang 
skom til Højskamling «. Festen $i$ år ville $i$ virkeligheden have været mere i Deres smag, end forrige år, og talerne var ingenlunde lange eller mange, hvilket De jo ikke kan lide. * Til slut meddeler Skau, at han har sendt Goldschmidt en beretning om Liedertafelfesten ved Haderslev, og den findes også benyttet af Goldschmidt i »Corsaren 1845 1/8.

Men Skaus brev har en efterskrift, og den er næppe blevet tilføjet så tilfældigt, som Skau søger at give det udseende af. Oven over sin meget kortfattede notits om Skamlingsbanke-festen ${ }^{26}$ havde Goldschmidt nemlig placeret en artikel med overskriften $\gg \mathrm{Om}$ pengeindsamling til of fentlige mænd «. Uden at nogen er nævnt ved navn, hedder det heri til slut: "Når nu en mand fremstår, en begavet, kraftfuld, højhjertet mand, og han virker aldeles gratis, så ved man nok, hvorledes folk er. Man har en underlig respekt for ham, men man ærgrer sig i grunden over, at man skal have denne respekt... Men, når man f. eks. giver en sådan mand 11.000 rbd., for at han kan købe en større gård og holde forvalter og således kunne rejse til København, så tit det skal være, og holde taler på enhver tid af dagen, så rejser folk over for at høre hans festtaler med en ganske anden, med en ren og ublandet fornøjelse. Så siger man ved hvert godt hib, han giver fra sig: Det har jeg betalt! Jeg har s'gu dog glæde af mine penge.

Skaus efterskrift ${ }^{27}$ har følgende ordlyd: $\$ J e g$ blev, efter at brevet var afsluttet, gjort opmærksom på, at jeg sigtes $\mathbf{i}$,Corsaren « for at have fået $\mathbf{1 1 . 0 0 0 ~ d a l e r ~ s o m ~ l ø n ~ f o r ~ m i n ~ o f f e n t l i g e ~ v i r k s o m - ~}$ hed. Jeg skal blot hertil bemærke, at jeg ikke har fået een skilling, og at jeg har købt gården uden at have forlangt penge. Derimod har man forlangt af mig, at jeg skulle gøre mig valgbar til stænderne, hvilket jeg lovede under den betingelse, at man skulle sikre mig et lån under sådanne betingelser, at jeg ikke ved min ejendomsforandring skulle blive en ødelagt mand. Så meget troede jeg at skylde kone og børn, og jeg indser ikke, i hvad hensigt De fortæller sligt, da det kun skader mig i min virksomhed herovre, uden at det $i$ nogen anden henseende kan gavne. - I ovrigt indrømmer jeg rigtigheden af Deres bemærkning, at danskere er $\mathbf{i}$ den grad forfængelige, at de ikke vil høre sandheden, når de ikke får betalt derfor, for at de dog kan smigre sig selv ved den indbildning, at de har fremkaldt det ved penge. 


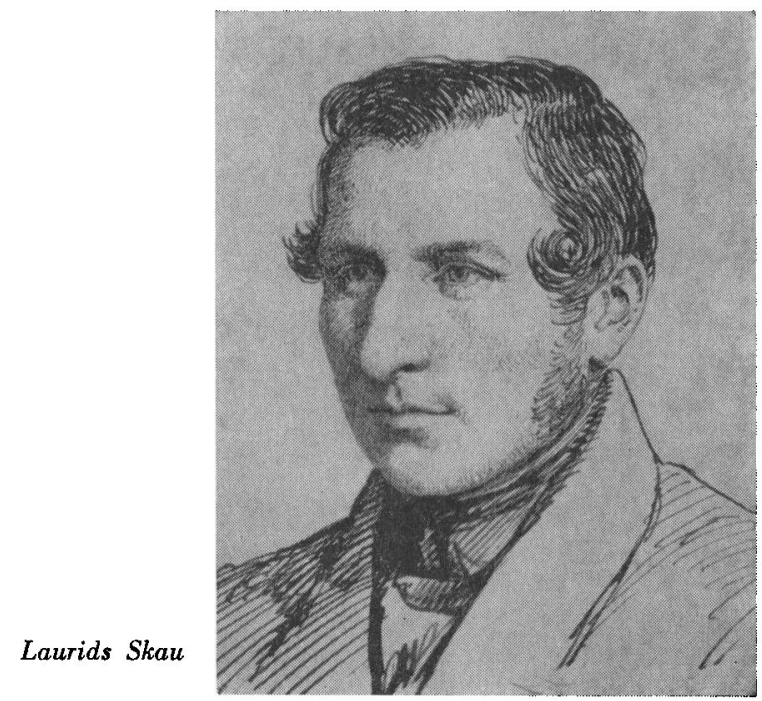

Men Skaus brev er kommet for sent, hvis det har skullet have nogen indflydelse på Goldschmidts bedømmelse, eller snarere: Goldschmidt har følt, at han endnu ikke havde skrevet sig fri af dette emne. Resultatet af hans overvejelser blev en artikel i stor opsætning, hvori han først dømmer Skau og søger at kyse ham med en rival blandt hans egne, en tidligere højskoleelev, men dernæst så usminket som muligt siger sin mening om det liberale københavnske borgerskabs holdning til Skau og den sønderjyske sag. ${ }^{28}$

\section{Laurids Skau og Peter Ravn}

(En erindring fra Skamlingsbanke).

Hvor glad blev jeg ikke, da jeg så Laurids Skau bestige talerstolen! Her, tænkte jeg, bliver du da endelig forløst fra efterveerne af den ugelange skandinaviske barselsstue. Jeg kendte Laurids Skau fra ifjor; jeg kendte hans lette tankegang, der lod sig følge uden spring; hans kernefulde udtryk, der ikke var plumpe oldtidsbrokker; hans varme og hjertelige foredrag, der aldrig steg ned til moderne pathos. Men, ak hvor forandret! Laurids Skau er ikke længere bonden fra Sommersted; han er en af de køben- 
havnske halvstuderede. Det, han havde at sige, var derfor kun nogle elegante og galante ubetydeligheder.

Men stille, I har intet at bebrejde ham. I har gjort ham til, hvad han er, lige så vist som I var udelagtige $i$, hvad han var. I har bedovet ham ved jeres akklamation, myrdet ham ved jeres feteringer. Den vamle kultus, I bereder enhver nogenlunde fremragende personlighed, har heller ikke forfejlet sin virkning: den har nivelleret ham. Men, som sagt, hvad kan han derfor? Da I rakte ham jeres hånd, anede han ikke, $\mathrm{i}$ hvilket vantrevet broderskab han indførtes.

Som jeg nu stod der mismodig og forstemt, da så jeg et tegn på Nordslesvigs manddom: det fødte atter en taler. Peter Ravn besteg talerstolen. Tænk jer en mand, der ikke er i besiddelse af det profetiske seerblik, der mangler "det af vid og agte nordisk skæmt idelig gennemkrydsede dybsind ", der ikke forkyndte en eneste dumdristig spådom til at besegles af de ørkesløse jabrødre, dẹ ikke fremsagde en eneste pikant grovhed, der, for at jeg skal sige alt, endog var uvidende om, hvilken betydningsfuld effekt man opnår ved først at lade stemmen synke ned til en hvisken og derpå med et barsk åsyn lade den som en uvejrssky rulle hen over mængdens hoveder. Tænk jer, den mand forstod dog at gøre én varm om hjertet; hans sprog var enfoldigt, men hjertelig varmt; snart alvorligt, snart efter lejlighed en smule spøgende, men aldrig sentimentalt-højtideligt eller kældermands-vittigt. Han sagde ikke andet, end hvad han følte.

Gid han må bevares Danmark ren og uforjasket! Gid han derfor aldrig må se København; gid han for alting vil sky de store byer, hvor så mange tusinde lømler går og vrøvler fra morgen til aften.

6: Goldschmidts åbenlyse angreb har naturligvis ikke kunnet undgå at gøre indtryk på Skau, og det fremgår da også af et brev til Carl Ploug, ${ }^{2 \theta}$ hvori han antyder, at Koch muligvis står bag ved Goldschmidts handlemåde. "Vi har vor ulykke med Koch. Det er et djævelsk menneske, som søger sin glæde $\mathrm{i}$ at sætte splid, hvor han kan... Jeg har en sagte anelse om, at Koch står i god forståelse og ivrig korrespondance med "Corsaren", og at han ikke 
er ganske uskyldig i, at både du og jeg skal holde for. Det er dog morsomt, sådan som Goldschmidt har fået lyst til vor pels, men det er imidlertid ikke så vanskeligt at forklare, thi forfængelighed og skinsyge er vel også det ondes ophav. Han kan imidlertid skade mig mere end dig, fordi jeg har ikke så dannet et publikum at bevæge mig iblandt .

Heri havde Skau utvivlsomt ret. Goldschmidts satire har virket langt stærkere i det sønderjyske provinsmiljø end i den akademiske verden, som Ploug tilhørte, men Ploug har rigtignok også måttet holde for $i$ adskilligt flere tilfælde. ${ }^{30}$ I sin gengivelse af Plougs optræden ved Skamlingsbanke-festen ${ }^{31}$ har Goldschmidt truffet både sin egen tids og senere tiders folketalere på kornet, og den skal derfor hidsættes her. Foruden at være et bidrag ud over det sædvanlige til Skamlingsbanke-mødernes historie vil den tillige danne den fornødne modvægt imod det ensidige indtryk, som beskæftigelsen alene med forholdet mellem Skau og Goldschmidt vil kunne skabe:

»Der var en stor fest på Højskamling. Unge og gamle, mænd og kvinder, folk fra det ganske Danmark var samlede. Og her herskede fryd og glæde, taler og sang, og man var mellem hinanden brødre.

Og iblandt det meget folk var der også en kandidat fra København. Og samme var vant til, når han lod sit ord høre, at finde stormende bifald; og han tav stille.

Og folk undredes såre, og de talte med hinanden derom og spurgte hinanden, hvorfor han tav.

Men han grundede på, hvorlunde han skulle finde ord, som var bedre end de andres ord. Thi han var argerrig og ville ikke, at andre skulle vinde større ære end han, der var kandidat og herre $i$ åndens rige.

Og alt folket så, at mørke skyer hvilede på hans pande. Og de sogte at forjage disse, og de vidste, at han gerne ville holde taler, og råbte derfor til ham: tal!

Og kandidaten rejste sig fra sit sæde og så med barsk blik på folket. Men folket nøs, hostede og rømmede sig, thi det ville, at hans ord skulle lyde over det ganske land og ikke forstyrres af utidig hosten, nysen og rømmen. 
Og kandidaten tav, til alle var blevet stille, og han tav noget endnu, og alle stod forventningsfulde.

Og endelig lød hans tordenrost, idet han spørgende sagde: Gives der et dansk folk? Og han tav nogen stund.

Og folket, som undredes over hans ord, tav også, og da det havde grundet nogen tid og ville svare ja, begav det sig, at han selv svarede: nej.

Og det forundrede folk undredes endnu mere, da han gav dette svar, og den ene så på den anden og tænkte: Hvad mon dette betyder? og hvad mon der nu vil følge?

Men kandidaten tog ordet, og han sagde: Skal der blive et dansk folk, da må denne anledning, som har forsamlet os, stifte det, og de slesvigske bønder blive skabere af det.

Og nørrejyderne undrede sig, og fynboer, lolliker og falstringer og sjællændere, ja selv slesvigerne gjorde det samme, så der var forundring over forundring.

Thi de troede alle at udgøre et dansk folk, og da de nu hørte, at det ikke var tilfældet, blev de alle til hobe meget ilde stemt, undtagen de slesvigske bønder, som følte sig stolte over det, at de skulle blive stamfædre for det vordende danske folk.

Og damerne betragtede de slesvigske bønder, og de hviskede til hinanden og lo.

Og der blev spist, og der blev drukket, og der blev sunget og der blev udbragt skåler. ${ }^{32}$ Og alle, både mænd og kvinder, blev meget lystige og glade, undtagen falstringerne og lollikerne, fynboerne og sjællænderne og alle dem, som ikke var udvalgte til stamfædre for det vordende danske folk.

Og de klogere af disse grublede og grundede. Og de fortrød nu, at de havde sagt til kandidaten: tal! Thi de indså alle grant, hvilke farlige følger det ville have for land og rige, når hans ord blev bekendte over al verden.

Og de kloge blev bange. Og jo mere de grundede og eftertænkte kandidatens ord, des mere bange blev de«.

7: Knud Fabricius har i sin redelige vurdering af Laurids Skau i den store Sønderjyllands Historie ${ }^{38}$ fremhævet Skaus hjælpsomhed over for sine venner som et smukt træk $i$ hans karakter. "Han kunne også tåle at høre sandheden, der ikke altid blev meddelt 
ham på en lige skånsom måde«. Disse ord finder deres bekræftelse ved Skaus holdning til Goldschmidt i tiden efter dennes kritik. Goldschmidt har åbenbart $184512 / 8$ sendt Skau et brev ${ }^{34}$ for at mildne indtrykket af sine udgydelser $i$ "Corsaren ", og Skau besvarede dette brev nogen tid senere: ${ }^{35}$ "Kære ven! Deres brev af 12. august overbeviser mig om, at jeg tør bruge denne overskrift, thi af venner får man alene sandheden at vide, og det er sjældent, jeg på så god en måde er blevet gjort bebrejdelser. Jeg kan i det mindste ikke opdage noget $i$ Deres brev, der vidner om andet end godt, og så fordærvet, som både De og andre måske tror, jeg er, så er jeg dog endnu ikke kommet så vidt, at jeg er døv for sandhed, ligesom jeg heller ikke bliver vred, selv om den åbenbare miskendelse ligger klart for mit øje, men kan endnu med naturlig ro og sikkerhed skelne mellem disse modsætninger «.

Der skulle unægtelig en god portion selvtillid - for ikke at sige ukritisk selvtilfredshed - til for at finde sig i alle de "sandheder", som Skau atter og atter og med større eller mindre grund måtte indkassere fra repræsentanter for det offentlige liv, men uden disse egenskaber havde han vel heller aldrig fået mod til at ombytte det tilbagetrukne liv i landlige omgivelser med sin udadvendte tilværelse. At han heller ikke selv ønskede at blive slået $i$ hartkorn med folk, som de er flest, fremgår med al ønskelig tydelighed af den "livshistorie«, der findes blandt hans efterladte papirer, ${ }^{36}$ og hans forsøg på at forklare sine private forhold for Goldschmidt ${ }^{37}$ som baggrund og undskyldning for hans handlemåde er $\mathrm{i}$ virkeligheden en forløber for den "livshistorie", som han skrev langt senere:

\Fra min tidlige barndom, da jeg var 2 år, har jeg været på en forunderlig måde tilsidesat både af forældre og lærere. Ingen af disse forstod at behandle en sådan karakter som min, jeg var en underlig original, man kaldte mig en særling, anså mig for stivsindet, fordi jeg før lod mig prygle end veg et skridt fra det, jeg bildte mig ind, var ret. Jeg havde et hurtigt nemme og læste meget; men i mit 10. år dristede jeg mig til at protestere imod noget vrøvl, som skolelæreren kom frem med, og følgen var, at jeg fik prygl, og da dette ikke hjalp mere, end at jeg næste dag begyndte på det samme igen, så var følgen atter, at jeg fik prygl, og således gik det, til jeg var 14 år. Hjemme anså man mig for en balstyrig 
knægt; jeg gjorde de forvovneste galskaber, tæmmede de vildeste heste, havde overordentlige kræfter, og det eneste, som man sommetider lagde mærke til, var, at jeg var påfaldende godmodig, så at jeg aldrig kunne tåle at se nogen lide, og gav den sidste skilling bort, når dette kunne hjælpe. Følgen heraf var, at jeg aldrig havde penge, og dannede derved en modsætning til min broder, som aldrig gav en skilling til bedste. Man kaldte mig en ødeland, og mine forældre behandlede mig som en sådan. De eneste mennesker, som lige til jeg blev konfirmeret elskede mig, var fattige og små børn, — de første, fordi jeg ikke alene gav dem, hvad jeg selv havde, men bad for dem hos far, og stjal endog $i$ fornødent fald pølse og brød o. s. v., når jeg ikke kunne få noget med det gode; - de sidste, fordi jeg forsvarede dem mod de stærkere, og derved ofte selv fik prygl, men havde også ofte den satisfaktion at sejre over overmagten, fordi jeg var stærk og glubsk tillige.

Fra mit 14. år gik jeg i Klosters skole, og denne gamle praktiker forstod bedre at tumle mig. Han tog mig fra ærens side, da han snart indså, at magten nyttede intet, og jeg blev fra den vildeste til den roligste dreng på mindre end et halvt år. Jeg gjorde stor fremgang i kundskaber, læste endog Voltaires skrifter og blev derved til en slags fritænker, endnu inden jeg kom af skolen. Historien var mit yndlingsstudium, og Munthes fædrelandshistorie kunne jeg på fingrene. Men Kloster grundlagde tillige i mig et gedigent had til embedsmændene, der har vedvaret indtil denne dag. Da jeg var konfirmeret, beskæftigede jeg mig med at læse aviserne samt hjalp min strenge far med sognefogedforretningerne, og fra den tid begyndte min far at tro, at jeg dog måske endnu kunne blive til noget. Min far var en dygtig forretningsmand, og jeg lærte snart af ham, at det ikke altid gik rigtig til, og nu studerede jeg hele nætter i arkivet, hvoraf jeg kom til kundskab om, at vor hele bestyrelse var et sandt miskmask af usselhed.

Omsider kom »Dannevirke«, og jeg greb bladet af alle kræfter under armene. I mit 20. år var jeg allerede gårdmand og fattigforstander, og da sognet netop havde processer med andre kommuner i den tid, så blev jeg meddelt fuldmagt til at gennemføre disse på sognets vegne, og inden jeg var myndig, havde jeg allerede plæderet 18 gange for retten imod vore storsnudede advokater; thi jeg både skrev og talte selv og ville aldrig bekvemme mig 
til at bruge sagfører. Lykken var mig huld; jeg vandt alle sagerne, og tillige stor anseelse. Min senere virksomhed er Dem tildels bekendt.

Efter denne - alt for lange - beretning vil jeg gå over til det, jeg egentlig vil skrive om, og jeg tror nu, at De kan se, hvad jeg onsker, det nemlig: at jeg fra tidligste barndom har så at sige måttet stå på mine egne ben.

Som følge deraf er jeg temmelig sejglivet, og når jeg også ligesom andre mennesker kan gøre mig skyldig i fejl, så håber jeg dog, at den grundkarakter, som fra de tidligste år er ligesom fremtvungen, ikke så let lader sig bortblæse; thi jeg er ikke dannet af bøger eller fuldproppet af munkelatin, men udviklet i praksis, og jeg har også gjort den erfaring, at de, som smigrer mest, er de farligste fjender, og de, der truer mest, er ikke værd at frygte for."

Den alvorligste anklage, som Goldschmidt offentligt havde rejst med sit indlæg om Skaus optræden på Skamlingsbanke, var påstanden om, at Skau havde forladt sit hjemlige miljø, og snart tilsluttede også Orla Lehmann sig denne klage $\mathrm{i}$ et privat brev til Skau. ${ }^{38}$ 1840'rnes Danmark var endnu i så høj grad et stænderdelt samfund, at en bonde een gang for alle var bundet til sin herkomst, og borgerskabet i København - tilmed byens liberale borgerskab - tålte ikke, at Skau forstod at optræde som en af deres egne - og kunsten at agere forstod han jo til bunds! -, men denne afvisning var også begrundet $i$ frygten for, at han derved skulle tabe ansigt blandt sine egne standsfæller. Det var jo som "den stolte riddersmand i bondekofte ${ }^{39}$, at han var blevet udbasuneret over for offentligheden.

Over for Goldschmidt søgte han at retfærdiggøre sig over denne anklage ved at fremføre følgende: $:^{40}$

*At jeg både $i$ det ydre og indre skal være vendt bort fra min stand, er en miskendelse; thi vel har De grund til at dadle min tale på Skamling, måske også enkelte ytringer i det private liv, men De må ikke derefter dømme mit indre, thi fordi jeg begår enkelte fejl, er jeg ikke fortabt, eller rettere, tabt for sagen, og det ville være for stor fordring, når De eller nogen ville forlange, at jeg skulle være fejlfri. Hvad nu det ydre angår, da kan det måske med nogen sandhed siges, at jeg ikke antyder »en bonde«, når jeg er i København, men med ikke mindste ret, når jeg er i Slesvig, 
thi her taler jeg og klæder mig som de andre bønder, ja meget simplere, og benytter mig ikke af ydre midler for at få indflydelse, men snarere ved mit had til aristokrati og bureaukrati, som jeg viser $i$ alle handlinger, sætter mig $i$ respekt ved vore demokratiske bønder.

Hvad københavnerne siger om mig, er i grunden ligegyldigt, men det er derimod ikke ligegyldigt, hvad bønderne siger, hvorfor jeg også både viser mig som en bonde og altid arbejder $\mathrm{i}$ bondestandens tjeneste.

Ved læsningen af Skaus lange retfærdiggørelsesbrev vil mange måske trække overbærende på smilebåndet, men det skal selvfølgelig bedømmes på baggrund af den tids forhold og med Skaus udsatte post $i$ tankerne, og der er vel heller ikke tvivl om, at hans udtalelser i brevets sidste del om sit forhold til bønderne har været ægte nok og også er blevet følt som værende $i$ overensstemmelse med sandheden. Kontakten med Goldschmidt fortsatte derfor uanfægtet af, hvad der havde været dem imellem, ja Skau leverede endda nye bidrag til "Corsaren*. Det sidste stykke, som han påviseligt har søgt at få optaget i Goldschmidts ugeskrift, blev ledsaget af et længere brev, ${ }^{11}$ hvori Skau oplyser en del om de karikeredes karakteristika. Allerede $i$ tidligere beskrivelser af haderslevske forhold havde de hyppigst omtalte fảet tillagt visse faste tilnavne. Amtmand Friedrich Johannsen var således "Sul$\tan \star^{42}$ og herredsfoged Otto Kier hans $>$ Storvezir $;^{48}$ i forlængelse af disse navne har Skau da kaldt konrektor Volquardsen for "Mufti". Brevets indhold taler i øvrigt for sig selv, men af Skaus slutningsbemærkninger vil man kunne forstå, hvorfor Goldschmidt ikke har turdet tage det pågældende indlæg. I udtog skriver Skau følgende: ${ }^{44}$

»Hoslagt noget til >Corsaren 4 . De ved jo nok, at jeg ikke kan skrive ganske således, som De kan bruge det, men så får De jo selv at lappe derpå. Det værste er, at fortællingen om den patriotiske slesvigholstenske forening er temmelig lang; den ville ellers i sin helhed virke fortrinligt. Den rammer nemlig de allerømmeste steder og støtter sig overhovedet til virkeligheden. At amtmanden og Kier er hovedmænd og hemmelige ledere, især den sidste, ved De sagtens, og at kirkekassens klingende mønt, som er under 
Kiers bestyrelse, bliver trolig benyttet, har [De] vel sagtens også hørt.

Min hovedhensigt er nu at benytte "Corsaren " som det sikreste middel til at afværge, at ingen bønder går ind $\mathrm{i}$ foreningen, hvilket måske dog ellers kunne ske, fordi det ingenlunde er svært for en embedsmand, når han har sølv til hjælp, at overliste og narre den uoplyste bonde. Men når han ser, at foreningen således vorder tilrakket, så vil han vogte sig, så meget mere, som det er imod hans demokratiske natur at arbejde i fællesskab med despotiske bureaukrater.

De nødvendige tegninger overlades naturligvis til Deres omsorg; Kier er ridder, lang og smal, med en stor næse. Meyer er ligeledes en lang rækel, med briller på næsen, da han næsten slet ikke kan se. Dr. Marcus er en lille mand med korte krumme ben og briller på. Muftien er konrektor Volquardsen, forhen redaktør af «Lyna «, nu medarbejder; han er puklet både for og bag, lille bitte, og en skinhellig kæltring. Præsidenten [sognefoged Nicolai Heinrich Posselt i Frørup] er en stor svær mand, forhen sømand, nu ejer af en gård. Sekretæren [Joh. Fr. Lorenzen i Jegerup] er ejer af en lille ubetydelig ejendom, meget drikfældig, dygtig tyk $i$ ansigtet med store øjne, der ligesom hænger ud af hovedet; og så er han noget korpulent. Glarmester Müller er et af de mest foragtede mennesker i Haderslev og må anses for menneskehedens udskud. Forhungret er han også, og hans kone er et offentligt fruentimmer. Da han nu er medlem, så syntes jeg, det var en alvorlig hån, når man lod ham og [landinspektør] Tiedemann figurere sammen.

At sætte Kier bag et skærmbræt syntes mig en god idé, da han virkelig er den værste djævel af dem alle herovre. Han er tillige despot af grundsætninger, en fanatisk bureaukrat og en listig ræv. S. Holst er en uhyre lang mand, der taler tåleligt tysk. Flere op: lysninger behøver De vel ikke for at lave karrikaturer.

Siden 1836 har vi arbejdet på at rive kirkekassen ud af Kiers klør, men endnu er det ikke lykkedes for os. Nu har han dog fået ordre fra kabinettet om at indsende alle regnskaber for de sidste 20 år; men dette hjælper jo ingenting. Kunne jeg have fået fat $i$ dem, så skulle vi få snurrige ting at se; men de vil sagtens stedse blive hemmelige for mig. -

Naturligvis er det ikke gået således til i den patriotiske forening, 
som jeg har fortalt; men dette gør vel ikke noget i København. Kunne man her få fat $i$ mig, så var jeg om en hals. De må forandre så meget, De lyster, men De må selvfølgelig også stå til ansvar. Men der er vist ikke stort $i$ vejen, thi jeg tror ikke, nogen vover at angribe Dem ad rettens vej."

8: Årene fra Peter Hiort Lorenzens nationalpolitiske demonstration i den slesvigske stændersal i 1842 til borgerkrigen i 1848 mellem danske og tyske i den gamle fælles helstat var i udpræget grad en overgangstid med brydninger mellem gammelt og nyt. På mange måder varslede disse år om, at noget nyt ville bryde frem, men tidens ledende mænd stod ofte famlende og usikre over for, hvad fremtiden bar i sit skød. Mening stod over for mening. Ikke alene stod danske og tyske over for hinanden med krav om at sætte skel ved Eideren eller Kongeåen, men selv blandt den nye tids mænd fandtes der nogle, som satte deres lid til, at frihedskravet lod sig forene med bevarelsen af helstatens politiske status, således som man havde taget den i arv fra tidligere slægtled.

Arvefølgespørgsmålet stod for den tids mennesker som noget aldeles afgørende for det danske monarkis fremtid, ikke mindst efter at håbet om en fortsættelse af den oldenburgske kongeslægt måtte opgives i løbet af 1844. Allerede kort efter nytår 1844 havde Goldschmidt rejst hele dette spørgsmål i en artikel med overskriften "Hertugen af Augustenborg ". Heri hedder det bl. a.: ${ }^{45}$

"Hvad vil den gode hertug af Augustenborg? Står han der blot til stads for at lade sig beundre med sin hertugkrone? $O$ nej, hertugen af Augustenborg er som bekendt den mand, hvis devise er » Ej blot til lyst «, men også til fordel. Han har noget $\mathrm{i}$ sinde, den gode hertug af Augustenborg.

Er da tiden kommet, hvorom vore liberale blade har drømt: Da han, understøttet af statholderen og den højstkommanderende $i$ hertugdømmerne, hans broder, vil lade sig proklamere til storhertug af Nordalbingien og lade den forjættede sol skinne over sit land Slesvig-Holsten; da Gülich, Beseler og Tiedemann skal indtræde $\mathrm{i}$ hans paradis, da Falck skal være hans historielaver og Todsen trompeter ved hans garde?

Nej, tværtimod! Han står der med fredens oliegren: Slesvig og Holsten skal aldrig skilles fra Danmark; de skal alle tre udgøre 
eet land, eet folk, have een Gud og een konge, og denne konge skal være - hertugen af Augustenborg.

Ah! - - -

Derfor var det altså, at han i sin tid erklærede, at han elskede det danske sprog så højt, ja talte det i sin families skød; derfor er den danske nationalitet i Slesvig blevet udryddet med "Lyna ss ild og *Itzehoer Wochenblatt «s sværd - for at skaffe hertugen af Augustenborg et bredt fodstykke til at stå på, når han træder op som tronprætendent.

Det står der, $\mathrm{i}$ "Kieler Correspondenzblatt «, at det danske folk vist ikke vil tage $\mathrm{i}$ betænkning at holde med hertugen af Augustenborg, når det tager hensyn til de »nærværende personligheder * (hertugen af Augustenborg og prinsen af Hessen).

Så har du da to tilkommende konger at vælge mellem, danske folk, og Gud give, at du nu lignede en pariser-opera-danserinde.

Når hun har to eller flere tilbedere, så giver hun den fortrinet, der byder mest.

Lad os holde auktion - hvem byder mest? - Vi kan lige så godt sælge os selv som lade os sælge, endsige give bort.

Byd da, I lysthavende!

Hvem er mest dansk: hertugen af Augustenborg eller prinsen af Hessen? - Gud skal vide det.

Hvem er bedst anbefalet? - Hertugen af Augustenborg anbefaler sig selv, prinsen af Hessen anbefales af Rusland.

Hvem er mest liberal, prins Wilhelms søn eller hertugen af $\mathrm{Au}$ gustenborg? - hvem giver en konstitution, republik, anarki? byd, mine herrer, byd, inden hammerslaget falder!

Lyksalige Danmark, du, som hidtil har været så lykkelig under een konge - du kan få to. Hvilken lyksalighed vil det blivel... For fremtiden skal der altså ikke eksistere slesvigholstenere, ikke engang danske - augustenborger eller hesser er løsenet....

Omend på skrømt var tanken om den augustenborgske hertugs tronkandidatur hermed fremført $i$ al offentlighed, og den slags gik naturligvis ikke ubemærket hen. Forsigtigvis gemmer Goldschmidt sig dog bag ved et skærmbræt ved at sige til censoren: "Spids ikke øren, kære justitsråd Reiersen, slik Dem ikke om munden med håbet om en beslaglæggelse, fordi vi siger, at vi heller ikke onsker 


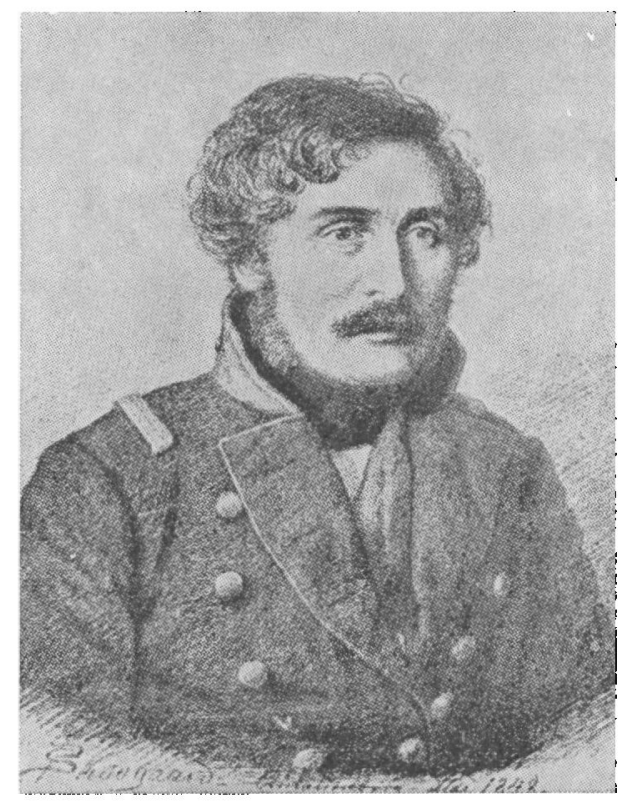

Anthon Frederik Tscherning.

prinsen af Hessen til konge - De begriber da, at vi ønsker vores egen kronprins og hans lige nedstigende slægt. «

I maj 1844 forlod kronprinsesse Mariane imidlertid sin gemal - den senere Frederik VII - uden at have opfyldt sin mission at skaffe Danmark en tronfølger, og den danske offenllighed måtte nu se $i$ øjnene, at der ikke ville blive nogen slige nedstigende slægt «; det oldenburgske kongehus ville uddø med Frederik VII. Sporgsmålet om, hvem der engang $i$ fremtiden skulle arve Danmarks trone, var dermed akut. Ved tronfølgeloven af $185331 / 7$ blev det som bekendt den senere Christian IX, der havde haft prins Wilhelm af Hessen-Philippsthal som formynder, og som i 1842 var blevet gift med Louise, en datter af landgreve Wilhelm af Hessen-Kassel. Men som antydet af Goldschmidt var den augustenborgske løsning af tronfølgesporgsmålet endnu ved midten af 1840'rne en mulighed, som man ikke ganske kunne lade ude af betragtning.

A. F. Tscherning var således inde på tanken i det selvsamme år. I foråret 1844 havde han lært hertug Christian August personligt 
at kende og modtaget det indtryk af ham, at han var en fyrste, s som med megen alvor beskæftiger sig med statens anliggender, som så fuldkomment har begrebet borgerfrihedens høje betydning, at han endog kan kalde til sit selskab og søge at underholde sig med en underordnet mand [som Tscherning selv], der kun rager frem over den almindelige hob ved den åbne modstand, han viser mod flere af de af fyrster hyldede, som retsgrundlag påkrævede politiske forudsætninger .... . Hvor mægtig en indflydelse måtte det ikke udøve på vort politiske liv, når der $\mathrm{i}$ hovedstaden fandtes en samlingsplads i samfundets højere kredse, hvor en så fri, en så uforbeholden forhandling af forholdene kunne finde sted; men hvor langt er vi ikke herfra endnuk Således lød nogle af de sætninger $i$ et takkebrev, som Tscherning $i$ begyndelsen af 1844 sendte hertugen. ${ }^{40}$

Brevvekslingen mellem hertug Christian August og Tscherning fortsatte endnu i $1845,{ }^{47}$ men på sin flere måneders bryllupsrejse gennem Jylland og Nordslesvig i efteråret 1845 opsøgte Tscherning ikke hertugen, skønt han var blevet opfordret dertil. ${ }^{48}$ Derimod havde han 1845 19/9 et møde i Haderslev med professor Christian Flor og Laurids Skau. ${ }^{49}$ Ved denne lejlighed er den augustenborgske tronfølgemulighed rimeligvis blevet drøftet mellem de tre, thi Skau siger senere i sit brev til pastor H. W. Krog-Meyer i Ulkebøl, ${ }^{\text {bo }}$ som han havde udset til sin kontaktmand hos hertugen: "Til hele ideens realisation er en forbindelse mellem hertugen og tvende offentlige personer nødvendig. Disse er professor Flor og kaptajn Tschernings.

Skau kunne ikke slippe denne drøftelse af sine tanker, og snart ser man ham tage initiativet til et forsøg på at få dem sat under debat. $P \mathfrak{a}$ en af sine mange rejser til København har han gjort Goldschmidt delagtig $i$, hvad sagen drejede sig om, ja foreslår ham endog $i$ et brev, skrevet efter hjemkomsten, at tage med på den påtænkte færd til Als:: ${ }^{\text {‘1 }}$

»Siden min hjemkomst har jeg næsten været syg hele tiden, og når jeg også en dag imellem har følt mig stærk, så har jeg dog ikke turdet vove mig ud på den rejse, jeg talte med Dem om. Nu er jeg dog nogenlunde rask igen og har derfor i sinde snart at afrejse til Als. Men De talte jo om at ville komme herover $i$ julen; hvad bliver dette forehavende til? Vi kunne jo dejligt have rejst 


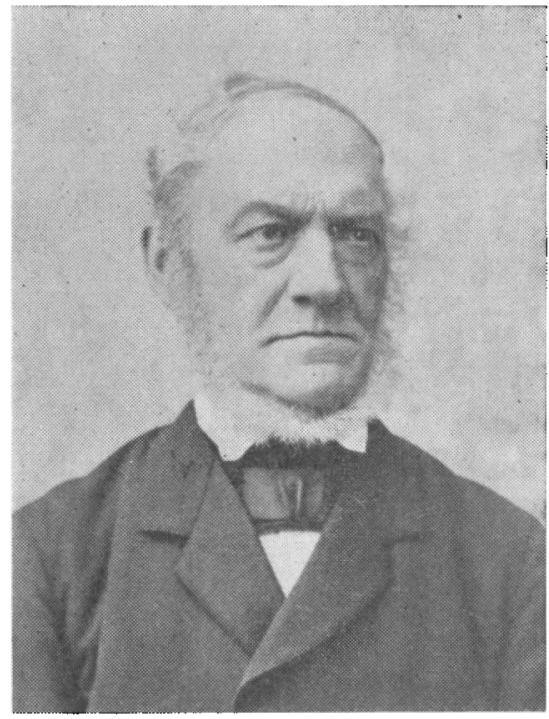

Carl Hloug.

sammen til Als, eller hvorsomhelst det skulle være. De kunne trænge til og have godt af en sådan udflugt, og jeg havde da ikke savnet en interessant rejsefælle. Thi De må vide, at jeg hører ikke til den slags kristne, som De har skildret $i$ "En Jøde "; $i$ den henseende er jeg, som De vist ikke tvivler på, ganske fri for fordom, medens jeg derhos må tilstå, at der rigtignok findes mennesker blandt mine trosfæller, som De fuldkommen rigtig har skildret. Mit valgsprog er forresten: „Jude, Heide, Muselmann - ist er brav, sei mein Mann *.

Skulle De endnu ikke have opgivet rejseplanen, da skriv med omgående post, og jeg skal da vide at træffe et sådant arrangement, at jeg - efter fattig lejlighed — kan være det bekendt, og De være fornøjet dermed. At De forbliver i mit hus, så længe De kan, og at De benytter det, som var det Deres eget, anser jeg som en naturlig selvfølge. Vel har jeg det ikke videre brillant; men ligesom jeg er overbevist om, at det ikke er den slags behageligheder, som kunne drage Dem til Slesvig, således tror jeg på den anden side at kunne skaffe Dem et venligt og hyggeligt opholdssted som også hjertelige og godmodige mennesker at tale med. Min kone, hos hvem ingen vil opdage nogen fuldkommenhed i det ydre, men der- 
imod et ædelt, kærligt og godmodigt indre, ville glæde sig over at være Deres værtinde; - og mine sønner, - ja de kender jo ikke Goldschmidt, men jeg tror, De i disse små poder vil finde sunde, kraftige vovehalse, der nok i sin tid kan blive brugbare. Se, kære Goldschmidt! her har De en beskrivelse af min familie; kom nu og se, om den er rigtig. *

Det kan ikke påvises, om Skau under sit Københavns-ophold også har informeret Carl Ploug om muligheden af at få en augustenborgsk tronfølge, men da deres korrespondance først igen tager fat i marts $1846,{ }^{52}$ synes der at have været dem noget imellem. Muligvis har Ploug da skarpt afvist de tanker, som Skau havde gjort til sine, ligesom Skaus ovennævnte sygdom også i første række synes at have været af psykisk art. Han klager således over ikke at have mødt "den fordums venlige modtagelse " under sit ophold $i$ hovedstaden. ${ }^{53}$ Det er også betegnende, at Orla Lehmann blot fik en antydning af, hvad planen drejede sig $\mathbf{o m} .^{54}$ Tscherning derimod var den, der blev udførligst underrettet, idet Skau sendte ham en genpart af det brev, hvori han henvendte sig til sin kontaktmand, præsten i Ulkebøl. ${ }^{.5}$

I brevet til Krog-Meyer findes nøglen til, hvad tankerne gik ud på: Hertugen skulle på sin ældste søns vegne gøre krav på arveretten til Holsten, mens han selv skulle indgå forlig med det danske kongehus og derved forberede en tronovertagelse i Danmark og Slesvig. Blev dertil hertugens anden søn gift med en svensk prinsesse, ville »mange skandinaviske hoveder vindes for sagen.

Nægtes kan det ikke, at den fremsatte plan i nogen grad vidner om politisk dilettanteri, men Laurids Skau stod ikke alene med ansvaret for, at den blev fremsat. ${ }^{58}$ Tscherning var i hvert fald $i$ det hele velvilligt indstillet over for de fremsatte ideer. ${ }^{57}$ \Jeg anser kampagnen på Als for meget vel begyndt; kan det blive et middel til at overtyde slesvigholstenerne om tåbeligheden og uholdbarheden af deres bestræbelser såvel for at danne et selvstændigt rige Slesvigholsten som især for at sætte dette under tysk varetægt, så har De vist vel «. Senere føjer han dog advarende til: * Vi må også vogte os for, at vor færd i nogen måde får skin af intriger, vore modstandere må vide så godt som vore venner, hvad vi vil, først derved vinder vore meninger styrke «.

Goldschmidts reaktion har hidtil ikke været kendt, eftersom 
hans to efterstående breve, der her bringes in extenso, hidtil har befundet sig blandt familien Skaus privatpapirer. ${ }^{88}$ Som man vil se, undslog han sig nok for at tage med, men gav i øvrigt sit bifald til planen:

\section{Kjore Laurids Skaul}

Kjøbenhavn, d. 10de Januar 1846.

Ret megen Tak for Deres venlige Brev og for den gjæstmilde Indbydelse. Desværre, jeg kan ikke komme ud af Buret, jeg maa blive, indtil jeg engang kan blive afløst. Da jeg fik Deres Brev, blev jeg saa utaalmodig efter at komme ud, at jeg i flere Dage ikke duede til den mindste Forretning. Nu er det gaaet over man kan finde sig i Alt.

Hvordan staaer det med Helbredet? Jeg kunde tydelig mærke af Deres Brev, selv om det ikke havde staaet der med tydelige Ord, at De ikke var rigtig oplagt, at De befandt Dem lidende. Op Dem, Mand! Ikke forknyt, fordi det gaaer Sneglegang!

$\mathrm{Nu}$ har "Fædrelandet $\times$ da faaet aaben Understøttelse ${ }^{50}$ og bliver holdt. Herregud, og slige Folk skal man agte! De tage 1400 Rbd. ud af et Selskabs Kasse til Dem selv. De er i godt Selskab, Laurids Skau.

Lev vel, vær hilset fra Deres hengivne

M. Goldschmidt.

D. 29de Januar 1846.

\section{Kjore Skau!}

Megen Tak for Deres Villie og Hensigt med at lade Lorenzen ${ }^{60}$ sende mig de omtalte Cigarer. Det gjør mig kun ondt, at han havde indpakket dem $i$ en Kasse af nyt Træ, der gav dem en saa vederstyggelig Afsmag, at jeg ikke kunde ryge en eneste. Kassen staaer her nu, og jeg veed ikke, hvad jeg skal gjøre med den. Jeg vil derimod særdeles gjerne have nogle fine Cigarer i en Kasse, der ikke lugter ilde.

Angaaende Deres omskrevne Reise og dens Grund, da giver jeg af ganske Hjerte mit Bifald til hele Planen, som jeg alt tidligere har sagt Dem. Jeg er beredt til, paa enhver lovlig Maade at kjæmpe for den, ligesom jeg maaskee er den første Danske, der offentlig har slaaet paa den Streng. Et eneste Venskabs-Raad er jeg saa fri at give Dem: Gaa ikke dybere ind paa Sagen end, at De hvert 
Øieblik kan trække Dem tilbagel Thi husk vel paa, at hele Sagen er rigtignok nu aldeles lovlig, men, erklærer Regeringen sig i Arvefølgesagen $i$ en anden Retning - hvad Gud forbyde - saa var Dem: Høiforræderi. Tro heller ikke, at noget Skridt, De gjør, bliver skjult længe. Vær, som der staaer i Skriften, snild som en Slange og uskyldig som en Due. Det er et mandigt, stolt og hæderligt Hverv, om det lykkes, men der hører ikke blot Frlighed og Loyalitet, men ogsaa den fineste Klogt til for at arbeide til Sagens Fremme. Kunde gjennem en høi Dame A[ugustenborgeren] og Kongen blive enige om Sagen, ${ }^{60}$ og fik De det Hverv at forberede Gemytterne, saa vilde jeg gjøre et Spring heelt op til Loftet af bare Glæde. Thi jeg holder dog en Klat af dette fordømte regn- og sludfulde Land. De kan derfor tænke Dem, med hvilken Interesse jeg venter paa nærmere Efterretninger. Skriv nu snart til

\section{Deres Ven \\ M. Goldschmidt.}

Laurids Skaus henvendelse til hertug Christian August løb ud i sandet, og dette blev ikke mindst tilfældet, fordi hertugen frygtede, at der stod andre kræfter bagved, som ville lokke ham ud af busken. Hertugen havde vel også på det tidspunkt knyttet sig alt for nøje til den slesvigholstenske sag til, at den foreslåede ordning ville have haft politiske muligheder. Som det ses af efterstående brev til Goldschmidt, ${ }^{61}$ indså Skau også dette:

- Det var sikkert et år for sent, jeg kom til Als. Arvefølgesagen, med hvad dermed står $\mathrm{i}$ forbindelse, har været afgjort forinden, og hertugen har opgivet håbet om at opnå noget og har sikkert ikke mod nok til [at] vove ny operationer i en anden retning end den, han hidtil har fulgt. Nu trækker han sig mere og mere tilbage fra alle og indtager blot en fornem adelig godsejers standpunkt, ligesom man fortæller, at han arbejder på sine døtres giftermål med Danmarks mægtigste godsejere, nemlig Reventlow på Lolland og Frijs på Frijsenborg. Efter et rygte er amtmand og kammerherre Scheel udnævnt til præsident i den slesvigholstenske regering, hvilket endmere tyder hen på, at statsenhedsprincippet ${ }^{62}$ fornemmelig spøger $i$ regeringens hoved; thi Scheel er en royalistisk despot, der ventelig med magt vil kue enhver bevægelse for at fremkalde en fuldstændig politisk død. Under sådanne omstændig- 
heder er det let muligt, at vi indlader os på en slags alliance med de af vore modstandere, som i demokratisk henseende er ærlige, for med fælles kraft at møde en fælles fjende. Jeg agter derfor at røre op i retsvæsenet og forlange edsvorneretten, også med hensyn til politiske forseelser. Da denne institution er alle konstitutionelle staters helligste palladium, så må man naturligvis vente en frygtelig modstand, først af bureaukratiet, fordi juryen er dettes grav; dernæst af juristeriet, som ikke kan finde sig i det simple »skyldig " eller »ikke skyldig", og endelig af kongen, fordi denne institution er af en altfor liberal natur, o. s. v. Jeg ved intet bedre at gribe til i en slig politisk sovetid, hvor alle fordringer er skrinlagte, fordi man æder, drikker og sover godt. Vi skal her $\mathrm{i}$ landet piskes ikke med svøber, men med skorpioner, inden vi vågner til politisk liv. \&

9: I vor tid er "Corsaren « jo mest kendt på grund af de angreb, som dette blad fremkom med mod Søren Kierkegaard, og det er vel også dette forhold, der må anses for grunden til, at Goldschmidt i oktober 1846 afstod "Corsaren ${ }^{63}$ og tog af sted på en flere måneders udenlandsrejse. For Goldschmidts forhold til Laurids Skau betød denne rejse i virkeligheden, at forbindelsen mellem dem ikke blev genoptaget senere. For Skau havde hovedformålet med kontakten vel også været ønsket om at benytte "Corsaren « i kampen mod slesvigholstenerne.

Skaus sidste bidrag til "Corsaren" handler om 》Festen pá Gram ${ }^{64}$ Gram slotshave var et yndet udflugtssted i pinsedagene. I 1846 endte festlighederne imidlertid med, at elever fra Ribe latinskole og Rødding højskole kom i håndgemæng med slesvigholstensksindede elever fra Haderslev latinskole, efter at de to parter først havde indledt en art sangerkrig. "Hoslagt sender jeg Dem noget, jeg i en fart har sammenskrevet i anledning af festen på Gram..., som De mulig kan bruge i "Corsaren «. Krogh og hans sønner trænger hårdt til tugtelse, fordi de er alle aristokrater, despoter og slesvigholstenske vindbøjtler... ${ }^{65}$

I $\gg$ Corsaren «s version af de stedfundne begivenheder hedder det bl. a.:

》I flere år har det været skik, at man på anden pinsedag er kommet sammen for at more sig $\mathrm{i}$ Gram slotshave. Også i år var 
der folk af alle klasser, bl. a. "Sultan" Johannsens søn og hans ven stenhuggeren, således også kammerjunker Kroghs to sønner med deres ven, inspektør Nissen, som de på denne dag havde gjort til politimester. Fra det øjeblik, da man havde givet Nissen politistokken $\mathrm{i}$ hånden, var han ikke længer et menneske, han var et væsen af spiritus og ild...

De to unge adelsmænd v. Krogh var trådt ind $i$ et telt, hvor nogle harpespillerinder spillede og sang. Ved en folkefest er man nedladende, man kan tilsidesætte den stive etikette, der påligger Slesvigholstens vordende regering, man indlader sig i passiar, man bliver varm; idet den ene harpespillerinde har sunget en glimrende bravour-arie, rejser man sig begejstret, griber hendes harpe og synger, for at også hun skal blive henrykt, med dyb følelse og sværmerisk ild: "Schleswigholstein meerumschlungen". Med denne sang er det nemlig, at slesvigholstenerne udtrykker deres kærlighed...e

Da sker der det, at »de unge danske bonder besvarede sangen med: »Danmark, dejligst vang og vænge". Midt i hr. v. Kroghs idyl lød altså krigstrompeten til ham...

Ved krigsråbet strømmede fluks slesvigholstenske skarer til teltet, og imidlertid havde "Danmark, dejligst vang og vænge « ført danske til teltets anden side, unge bønder, højskoleelever fra Rødding og primanere fra Ribe. Og da hr. v. Krogh nu så sine skarer, så, at de var tidobbelt talrigere end de danske, greb han endnu engang harpen og sang en triumfsang, og dette var en sang, hvilken inspektør Nissens umusikalske ore opfattede sorn det vilde, sønderrivende skrig.

Nissen kom altså styrtende ind; han vaklede, han var purpurrød, rød som druens blod, for at tale poetisk... Philip Nissen lod sig ikke sige to gange, at danske $i$ hertugen af Augustenborgs stater havde sunget "Danmark, dejligst vang og vænge"... og styrtede mod de danske.

Nu må man imidlertid lægge mærke til terrænet: De danske stod i klynge uden for teltet, og man kunne kun komme til dem ved at passere en temmelig smal dør. I denne dør kom Philip Nissen ved sin uforsigtige fremrykken i klemme, medens hele den slesvigholstenske hær, højt syngende og blind af raseri, slog løs bag ved ham. Philip Nissen ville vende $s^{\circ} g$ om for at slå sine ven- 
ner fra sig, men han sad som sagt i klemme og måtte slå på de danske, som ikke gjorde ham den ringeste fortræd og tværtimod medlidende råbte: > Hold op! « Men slesvigholstenerne, som troede, at de bad om pardon, slog kun endnu heftigere los på Philip Nissen. Nu brølede Philip Nissen $>$ Schleswigholstein meerumschlungen * for at tilkendegive, at han blev omslynget og maltrakteret på alle kanter, men hans hær misforstod også dette signal og hørte deri det sædvanlige sejrs- og kampråb, dens begejstring steg til et sandt raseri, og den slog med næsten overmenneskelige kræfter, indtil endelig Philip Nissen sagte stonnede "Schleswigholstein meerumschlungen « og sank halvdød ned «.

10: Goldschmidts store udenlandsrejse fra efteråret 1846 til efteråret 1847 betegner det afgørende vendepunkt $i$ hans indstilling til tidens nationalpolitiske problem. Han havde ude i Europa lært et land at kende, hvor forskellige folkeslag formåede at leve fredeligt sammen, nemlig Schweiz. Et dybt indtryk havde forhandlingerne i Berns kantonalforsamling gjort på ham: "Begge parter forstår tysk og fransk, men de tyske medlemmer taler tysk, og de franske svarer på fransk $\propto^{66}{ }^{66}$ I Schweiz havde han fundet konflikten mellem nationalstatstanke og humanitetsprincip løst på en for alle parter tilfredsstillende måde, og han vendte tilbage til Danmark med den faste overbevisning, at en demokratisk helstatsordning måtte være fremtidens løsning af det dansk-tyske problem, ${ }^{67}$ men dermed kom han i strid med hele den danske liberale opposition, for hvem det nationale mål var grænsen ved Eideren.

Ved det forste store Casino-møde 1848 11/3 talte Goldschmidt derfor for døve øren, da han advarede imod, at man i København søgte at indlemme Slesvig $i$ en konstitutionel forbindelse med Danmark uden at spørge det slesvigske folk $\propto{ }^{68}$ Hans ord vakte voldsom larm i salen, og dirigenten $L$. N. Hvidt afbrød ham for at minde ham om, 'på hvilket sted han stod!* Efter nogen hyssen lykkedes det ham igen at komme til orde, hvorefter han afviste tidligere taleres sammenligning mellem Slesvig og de andre danske landsdele. Hvis Lolland ville $\mathrm{i}$ forbindelse med Sverige, måtte man have lov til at tvinge det bort fra en sådan tanke, havde man sagt, og det samme måtte følgelig gælde for Slesvigs vedkommen- 
de, men dette afviste Goldschmidt: „Lolland er ikke ved sædvaner, vigtige institutioner og kongelige løfter bragt $\mathrm{i}$ forbindelse med Sverige, således som Slesvig med Holsten. Derfor protesterer jeg i frihedens og retfærdighedens navn imod, at Slesvig uden at adspørges tvinges til en forening med Danmark! Atter blev han afbrudt, og Tscherning tog da ordet for at fastslå, at dette ikke lod sig gøre, hvorefter mødet hævedes, "fordi klokken var 10! Den følgende aften søgte Goldschmidt endnu engang at vinde tilslutning for sine tanker. Det var ved mødet $i$ s Hippodromen ", som Håndværkerdannelsesforeningen havde indkaldt til, men her tog Orla Lehmann henimod midnat ordet som sidste taler og *bjergtog hele forsamlingen med sin veltalenheds henrivende kraft $4 .{ }^{.8}$

Skau blev underrettet om Goldschmidts optræden $i$ et par breve fra pastor J. W. Marckmann, ${ }^{70}$ samt gennem referatet $i$,Fædrelandet «s følgeblad. Marckmann hævder, at Goldschmidt var blevet slynende hævnsyg " over den behandling, som han havde været udsat for. Skau mente dog, at en slesvigsk adresse i eiderdansk retning nok skulle stoppe munden på ham. Til Carl Ploug ${ }^{71}$ skriver han således: *Den "små " Goldschmidt skal vi nok herovre fra gøre kål på, thi ved at fordre forbindelsen med Danmark opretholdt og fuld adskillelse fra Holsten både i militær og finanser, hvilket nu udtrykkelig står $\mathrm{i}$ adressen, gøres hans påstande til logn *.

De citerede linjer viser, hvor langt Skau og Goldschmidt i virkeligheden stod fra hverandre. For Skau og hans ligesindede var det gamle dansk-tyske monarkis dage talte, og af dem måtte det anses for politisk bagstræveri, når Goldschmidt fortsat fremturede med Helstaten som politisk ideal, tilmed midt under borgerkrigen mellem landets danske og tyske befolkning. Det var uhjælpeligt for sent, når han fremholdt idealet fra mønsterlandet Schweiz, således $i$ anledning af dette lands nye forfatning af 1848 12/9, hvori der var blevet proklameret en helstat af forskellige nationaliteter og med tre anerkendte nationalsprog. $\gg$ Er nu danskere, slesvigere og holstenere mere forskellige end bernere, genfere og tessinere [tysk-, fransk- og italiensktalende schweizere]? ... Hvorfor kunne stammerne heroppe i Norden ikke have dannet en helstat, hvad forbryderisk var der $i$ tanken herom? « $^{72}$

Altsammen i vore oren meget rigtigt, men det var bare ikke 
tidens tale! Nok havde helstatspatriotismen endnu dybe rødder $\mathbf{i}$ samfundets almue, men begivenhederne i 1848 havde givet borgerskabet den politiske magt, og det politiske ideal for den nye tids mænd var nationalstaten med den historiske grænse ved Eideren. Af dem måtte Goldschmidt finde sig $i$ at blive slået $i$ hartkorn med enevældens gamle dansk-tyske embedsmandsoverklasse, skønt han atter og atter fastslog den demokratiske helstat som sit politiske ideal, således $i$ en programartikel under overskriften , Føderativstaten ${ }^{73}{ }^{73}$ Heri sammenfatter han til slut sin politiske opfattelse i disse linjer: »Det væsentlige $\mathrm{i}$ vore politiske bestræbelser har været at påvirke den offentlige mening og derved regeringen således, at man benyttede sig af de udenrigske forhold $i$ en anden ånd end Martsministeriets, henvendte den omhyggeligste opmærksomhed på at få hertugdømmet Holsten med under statshøjheden, hvilket ikke strider mod fredspræliminarierne, som indrømmet af vore tyske modstandere. Imidlertid har vi ikke opgivet opmærksomheden og omhyggeligheden for Slesvig og den danske nationalitet, men opstiller derhos for det hele rige et frihedens og mildhedens princip, som - man fører krig eller ej — altid må blive det, man til sidst tyr til som en nødvendighed * .

Helstaten havde vel også før udenlandsrejsen været den bærende faktor i Goldschmidts opfattelse af den danske stat. I hvert fald eksisterede den jo som en politisk realitet, og det var derfor, at han ved årsskiftet $1845-46$ havde vist sympati for Laurids Skaus plan om at søge kontakt med hertug Christian August af Augustenborg. I det foran citerede brev af 1846 29/1 har han jo tydeligt tilkendegivet sin velvillige indstilling til en sådan tanke, men at Skau havde arbejdet for sin plan ud fra eiderstatstanken, blev Goldschmidt først klar over, da han ved læsningen af Droysen og Samwers bog Die Herzogthümer Schleswig-Holstein und das Königreich Dänemark f fik kendskab til ordlyden af Skaus tidligere omtalte brev til pastor Krog-Meyer i Ulkebøl, ${ }^{74}$ og i en anmeldelse af denne bog benytter han lejligheden til politisk og menneskeligt at tage afsked med sin fordums ven.

Brevets indhold er ret karakteristisk, siger han indledningsvist og fortsætter derefter: 'Skau begynder i naiv forfængelighed brevet med en selvros over den anstand, ridderlighed og tillige sandfærdighed, hvormed han i Haderslev har udbragt hertugens skål, 
over de planer, der bevæger sig i hans egen offentlige persons indre o. s. v. Vi ser egentlig intet ondt heri, men en mand, der skriver så godt for sig, som Skau unægtelig gør, kunne gerne have taget sig lidt mere i agt og ikke leveret et bilag til påstanden om » die fratzenhafte Eitelkeit der Dänen «. Dernæst går brevet over til at tilbyde hertugens familie sen karriere som få fyrstehuse og måske intet andet", imod at han slutter forbund med de danske og navnlig på folgende måde: Han skal smigre den danske nationalforfængelighed (meningen er vel: vise agtelse for den danske folkefølelse), hvilket han fra et ridderligt standpunkt godt kan gøre; thi som fyrstelig person skylder han folket $i$ Nordslesvig at hjælpe på dets naturlige, nationale udvikling; til en begyndelse kunne han tegne sig for bidrag til højskolen i Rødding. Hertugen skal dernæst gøre arvefordringer på Holsten for sin ældste søn, berede sin anden søn vej til den danske trone (med Slesvig), men tillige formæle ham med en svensk prinsesse samt forberede en konstitution. Til den ende var det nødvendigt, at han søgte venskab med kongen og kronprinsen, kom til Sjælland og søgte at blive minister, og da ville man, støttende sig på England og Frankrig, udelukke hesserne fra tronfølgen og »blæse Rusland et stykkes. Foruden at søge venskab med kongen, kronprinsen, Frankrig og England var det sluttelig nødvendigt, at hertugen sluttede forbindelse med d'hrr. Flor og Tscherning, nemlig med hin som repræsentant for det danske aristokrati, med denne som den talentfulde og diplomatiske fører for demokratiet. Endelig lover hr. Skau sin egen hemmelige og offentlige understøttelse for dette Damon- og Pythias-venskab,

\section{Ich sei - gewährt mir die Bitte -}

In Eurem Bunde der Dritte,

og antyder med sin sædvanlige beskedenhed, at denne understottelse ikke vil være uden betydning. \&

"Mod planens ærlighed og gode hensigt fra partiets standpunkt er intet at sige", fortsætter Goldschmidt, men hvad han har imod den, er dens seiderdansk-skandinaviske program «, men med dette program var Skau i samklang med den almindelige opfattelse i tiden, mens Goldschmidt stod fremmed over for »ånden fra 48 «.

Vor tid vil måske nok $i$ nogen grad være tilbøjelig til at give 
Goldschmidt medhold, i hvert fald har vi bedre forudsætninger for at forstå hans standpunkt, men for sin egen samtid stod han ene. Politisk var og blev han fra nu af *hjemløs * - for at bruge en af hans egne romantitler. Skaus politiske rolle var derimod ikke udspillet. Mens Goldschmidts politiske optræden forlængst var glemt, stod Skau i begyndelsen af 1860'erne som lederen af den danske bevægelse i vort grænseland, en stilling, som først døden rev ham ud af.

\section{NOTER Og HENVISNINGER}

1. Peder Skau til sin søn 1898 1/1 (LA. Peder Skaus arkiv).

2. Bevaret er $\mathrm{i}$ hvert fald kun: Goldschmidt til Peter Chr. Koch 1844 12/7 og for 19/7. (KB. NKS 1763; trykt i udtog: Peder Lauridsen: Da Sonderjylland vaagnede (herefter citeret: Da SJy vaag), VI, s. 165 f. og 166, samt in extenso: Breve fra og til Meir Goldschmidt, udgivne af Morten Borup (herefter citeret: Br Goldschm), nr. 12 og 13.

3. M. Goldschmidt: Livs Erindringer og Resultater I, s. 330 (i ny udgave fra 1964: s. 179; Morten Borups udgave fra 1965: I, s. 181).

4. M. Goldschmidt: Livs Erindringer og Resultater I, s. 358-362, 364 (1964-udgaven: s. 195-197, 199; 1965-udgaven: I, s. 193-194, 195).

5. Ove Thomsen, redaktor og politiker, 1801-62, 1836-47 udgiver af >Fyens Avis«, stænderdeputeret, 1849 postmester i Assens, 1849-52 og 1853 folketingsmand.

6. Hans Kyrre: M. Goldschmidt, I (1919), s. 79, samt note 6.

7. Goldschmidts tale er efter Dannevirkers gengivelse trykt $\mathbf{i}$ Karl Hede: Højskamling eller Skamlingsbankes Historie (1882), s. 106 f., og i Jakob Petersen: Skamlingsbanken 1843-1943 (1943), s. 99 f. I Karl Hedes bog finder man de udforligste gengivelser af de forskellige festtaler på Skamlingsbanke.

8. Marckmann til Koch 1845 10/5 (KB. NKS 1763; trykt: Skaus Brevv s. 282).

9. Altonaer Mercur`, nr. 169, her citeret efter "Sønderborger Ugeblad* $184431 / 7$.

10. Citeret efter $>$ Sønderborger Ugeblad 1844 9/10; smstds. 1844 16/10.

11. Skau til Goldschmidt 1845 8/1 (KB. NKS 1727; trykt: Br Goldschm nr. 22).

12. Da SJy vaag $\mathrm{V}$, s. 59 .

13. Goldschmidt til Koch 1844 12/7 (KB. NKS 1763; trykt: Da SJy vaag VI, s. 165 f., og: Br Goldschm nr. 12).

14. Goldschmidt hentyder til de liberales russerhad; russerne var på den tid enevældens beskyttere. Sangen var blevet sunget ved de nordiske studenterfester.

15. Skau til Goldschmidt 1845 8/1 (KB. NKS 1727; trykt: Br Goldschm nr. 22). 
16. Goldschmidt til Skau udat. (KB. NKS 1727; trykt: Br Goldschm nr. 21).

17. Skau til Ploug 1844 5/8 (KB. NKS 3316; trykt i udtog: Da SJy vaag VI, s. 171-175, og in extenso: $H$. V. Gregersen: Laurids Skaus Brevveksling med politiske Venner i København, herefter citeret: Skaus Brevv).

18. Lange Erich var sognefoged i Hoptrup sogn Erich Laygaard (Erik Ladegaard); de ovrige er: amtmand Friedrich Johannsen, Haderslev, gdr. Hans Skau, Styding (ikke i slægt med Laurids Skau), herredsfoged i Gram herred Otto Kier, pastor Siwert Andresen i Hammelev. - - Ussingsk sejghed hentyder til Tage Algreen Ussings optræden i Roskilde stænderforsamling.

19. Skau til Goldschmidt 1845 8/1 (KB. NKS 1727; trykt: Br Goldschm nr. 22).

20. Trykt opfordring af $184520 / 4$, underskrevet af sde syva: $H$. N. Clausen, J. C. Drewsen, H. P. Hansen, L. N. Hvidt, J. E. Larsen, N. J. Meinert, J. F. Schouw (trykt: Skaus Brevv s. 89).

21. Corsarene 1845 25/7, $1 / 8$ og $15 / 8$.

22. -Valgerdac var pseudonym for lærerinden Marie Arnesen (1824-91). Hendes optræden inspirerede J. L. Heiberg til lystspillet, Valgerdac (1847).

23. Corsaren $1845 \quad 18 / 4$.

24. Skau til Goldschmidt 1845 27/7 (KB. NKS 4252; trykt: Br Goldschm nr. 35).

25. Skau opretholdt i de kommende âr fra tid til anden forbindelsen med Marie Arnesen. I brev af 1848 26/5 (KB. NKS 1727) foreslår hun et møde ved Brahetrolleborg spå en bænk $i$ den lange allé mellem kl. 7 og 8 eller evtl. søndag formiddag «.

26. Corsarene 1845 25/7.

27. Skau til Goldschmidt 1845 27/7 (KB. NKS 4252; trykt: Br Goldschm nr. 35).

28. Corsaren $184515 / 8$.

29. Skau til Ploug 1845 22/8-24/8 (KB. NKS 3316; trykt i udtog: Da SJy vaag VIII, s. 100-103, og: Højskolens Ungdomstid i Breve I, s. 71-72, samt in extenso: Skaus Brevv).

30. F. eks.: s Corsaren 1845 18/4: Hr. Ploug holdt to taler, altså sin 24de. Nu kan hans taler holde sølvbryllup, hvad dag det skal værec; 1845 4/7: $H r$. Ploug, der mest talte om sig selv\&; 1845 11/7: -Fædrelandete er dog af alle danske blade det bedst redigerede, og det, der har de fleste korrespondenter. Der gives ikke en norsk eller svensk stad, ikke en landsby, ikke et bondehus, selv i Nordlandene og Lapland, hvorfra det ikke får efterretninger. Derved er det formodentlig, at, Fædrelandete er blevet sat istand til at berette, at ved aktionen for den tale, hr. Ploug holdt i Kalmar, -blev hans navn bekendt over hele Sverige og Norge.

31. CCorsaren 1845 1/8. - Plougs tale findes bl. a. trykt i Karl Hede: Højskamling, s. 129-130. Ploug havde i talen spurgt:, $\mathrm{Er}$ der et dansk folk? Til sidst siger han: IIdet Slesvigs bønder har rejst sig til kamp for deres nationale selvstændighed, har de udsået spiren til et dansk folk, og jeg vil slutte med at udbringe et leve for dette folks spire, for denne udviklings bærere, Nordslesvigs bondestand . 
32. Et brev fra redaktør Emil Hyphoff, >Ribe Stiftstidende , til Laurids Skau fra 1845 25/7 giver et indtryk af, hvad Goldschmidt hentyder til: sTak for sidst! Efter at have sagt dig (dus er vi jo altsi̊, endskønt vi endnu ej have drukket derpå - gid Satan for resten havde al drikken og æeden; jeg var nærved at se mig gal i hovedet på den evige svælgen $i$ det store telt på Hojskamlingen efter middagsbordet sidst: som om Slesvig reddes på den måde, som om man kan få bugt med slesvig-holsteinerne derved, som om man kun æder og drikker sig mod til; nej den slags mod damper bort med rusen; havde det endda været advokat-blod, man drak, og stegte advokater, man ad, det kunne jeg forsta), men det var da en nederdrægtig parentes * (KB. NKS 1727).

33. Sønderjyllands Historie IV, s. 284.

34. Ikke bevaret.

35. Skau til Goldschmidt 1845 6/9 (KB. NKS 4252; trykt: Br Goldschm nr. 36).

36. Blade af Laurids Skaus Livshistorie. Udgivne af hans Broder Peder Skau, Bukshave. Århus 1908. Manuskriptet har hidtil varet i familiens eje, men er nu afleveret til KB. Hindskriftsamlingen.

37. Skau til Goldschmidt 1845 6/9 (KB. NKS 4252; trykt: Br Goldschm nr. 36). - Munthes fædrelandshistorie er skolemanden Eiler Munthes bog fra 1806, $\gg$ De vigtigste indenlandske Tildragelser og de mærkeligste [mærkværdigste] Personers Levnedsbeskrivelser ^, der var en læse- og lærebog i fædrelandshistorien.

38. Lehmann til Skau 1845 30/8 (KB. NKS 1727; trykt: Da SJy vaag VIII, s. 103-107, og: Skaus Brevv).

39. Udtalt af Orla Lehmann på Skamlingsbanke 1844 4/7, se: Karl Hede: Højskamling, 1882 , s. 93.

40. Skau til Goldschmidt $18456 / 9$ (KB. NKS 4252; trykt: Br Goldschm nr. 36).

41. Skau til Goldschmidt $184523 / 10$ (KB. NKS 4252; trykt: Br Goldschm nr. 38).

42. *Corsaren 1844 5/4: sultan Johannsen i Haderslev *.

43. "Corsaren 1844 19/7: „Hvorledes man i det lykkelige Land, Schleswig-Holstein, kan faae en Adresse.

44. Skau til Goldschmidt 1845 23/10 (KB. NKS 4252; trykt: Br Goldschm nr. 38).

45. Corsaren $184517 / 1$. Rusland betragtedes almindeligt som enevoldsstyrets højborg (se også note 14); derfor var Goldschmidt og mange liberale også betænkelige ved den hessiske tronfølge.

46. Af Anthon Frederik Tschernings efterladte Papirer. Udgivet af hans efterlevende Familie (herefter citeret: Tschernings Papirer) II, s. 338-341.

47. Tschernings Papirer II, s. 241-249.

48. Tschernings Papirer I, s. 34 .

49. Skau til Marckmann 1845 23/9 (RA. Marckmanns arkiv; trykt: Skaus Brevv).

50. Tschernings Papirer II, s. 254.

51. Skau til Goldschmidt $184523 / 12$ (KB. NKS 4252; trykt: Br Goldschm nr. 40). 
52. Skau til Ploug 1846 4/3: Det er nu en rum tid, siden jeg skrev sidst til dig — måske et halvt år (KB. NKS 3316; trykt i udtog: Da SJy vaag VIII, s. 123-127, og in extenso: Skaus Brevv).

53. Skau til Lehmann 1845 23/12 (RA. Orla Lehmanns arkiv; trykt i udtog: Da SJy vaag VIII, s. 121-122, og in extenso: Skaus Brevv).

54. Se note 51 .

55. Tschernings Papirer II, s. 250-256; Ludvig Hertel: Hans Wilhelm Hertel (1897), s. 138-140. Brevet er dateret Hovst pr. Haderslev $18467 / 1$.

56. Således vil Peder Lauridsen gerne have denne sag fremstillet, se: Da SJy vaag VII, s. 83.

57. Tscherning til Skau 1846 20/1 (KB. Håndskriftsamlingen, trykt: SJy Årb 1963, s. 73-77).

58. Nu afleveret til KB. Håndskriftsamlingen. Da disse breve ikke har været trykt tidligere, bringes de i original retskrivning.

59. Der var foretaget en indsamling til fordel for $>$ Fædrelandet .

60. Der er sikkert tale om Carl Lorenzen, en sun af Peter Hiort Lorenzen, der på den tid var købmand i Haderslev, men siden udvandrede til U.S.A. "En høi Dame er Christian VIIIs dronning Caroline Amalie, som var hertug Christian Augusts søster.

61. Skau til Goldschmidt 1846 18/6 (KB. NKS 4252; trykt: Br Goldschm nr. 49).

62. Statsenhedsprincippet « eller Helstaten som princip blev netop fastslảet af den danske regering med det Abne Brev af 1846 8/7 (trykt i faksimile: Sønderjyllands Historie IV, s. 326, og: Sonderjylland Historisk Billedbog. Tiden indtil 1864, s. 226). - Skaus opfattelse af helstatsmanden $L$. N. Scheel ændredes snart til det bedre, jvf. Skaus Brevv s. $104,178,400,437$.

63. Hans Kyrre: M. Goldschmidt, I, s. 90.

64. Corsaren * 1846 26/6.

65. Skau til Goldschmidt $184618 / 6$ (KB. NKS 4252; trykt: Br Goldschm nr. 49).

66. s Nord og Syd I (1848), s. 249.

67. Nord og Syd I (1848), s. $317 \mathrm{ff}$.

68. Fædrelandet 1848 13/3 med følgebladet, Forhandlinger om Danmarks og Slesvigs constitutionelle Forening «; Goldschmidts kritik af de givne referater: "Nord og Syde II (1848), s. 85; Hans Kyrre: M. Goldschmidt, I, s. 189-190.

69. Fæadrelandet «s udtryk i referatet 1848 13/3; Goldschmidt skriver i overensstemmelse hermed: , Det var ikke muligt $i$ ojeblikket at besejre ham og unddrage folk det trylleri, han kan udøve ved ordet. Hans talegaver er i høj grad mærkværdige. Han taler egentlig ikke skønt, men blomstrende. Ordene slutter ikke om tanken som det gennemsigtige draperi om statuens dejlige lemmer, men sprudler frem som kaskader, som blomsterbuketter, guirlander og spiller i alle farver. Hans tale fryder og blænder; selv hans modstander, der erholder stødet, får det, som det egner og anstår sig, ikke med oksen, men som med en fin, uendelig fin pariserkárde. Modstanderen lytter med velbehag, inden klingen sidder $\mathrm{i}$ hans hjerte, og han er dad* ( Nord og Syd* II (1848), s. 95; Hans Kyrre: M. Goldschmidt, I, s. 192. 
70. Marckmann til Skau 1848 16/3 og 18/3 (KB. NKS 1727; trykt: Da Pol Br IV, s. 127 og 131-132, samt: Skaus Brevv).

71. Skau til Ploug 1848 21/3 (KB. NKS 3316; trykt: Da SJy vaag VIII, s. 208-210, samt: Skaus Brevv).

72. Hans Kyrre: M. Goldschmidt, I, s. 196.

73. > Nord og Syd«, II, 1849, s. 1-14.

74. Droysen \& Samwer: Die Herzogthümer Schleswig-Holstein und das Königreich Dänemark. Aktenmässige Geschichte der dänischen Politik seit 1806, 1850, s. 204-207, 404-408. Goldschmidts kritik i > Nord og Syd IV, 1850, s. 50-53. 